\title{
Flavonoids are promising safe therapy against COVID-19
}

\author{
Moza Mohamed Alzaabi • Rania Hamdy • Naglaa S. Ashmawy • \\ Alshaimaa M. Hamoda • Fatemah Alkhayat • Neda Naser Khademi • \\ Sara Mahmoud Abo Al Joud • Ali A. El-Keblawy • Sameh S. M. Soliman (D)
}

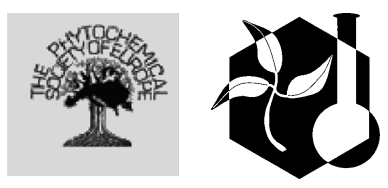

Received: 28 January 2021 / Accepted: 28 April 2021/Published online: 22 May 2021

(C) The Author(s), under exclusive licence to Springer Nature B.V. 2021

\begin{abstract}
Flavonoids are a class of phenolic natural products, well-identified in traditional and modern medicines in the treatment of several diseases including viral infection. Flavonoids showed potential inhibitory activity against coronaviruses including the current pandemic outbreak caused by the severe acute respiratory syndrome coronavirus 2 (SARSCoV-2) and designated as COVID-19. Here, we have collected all data related to the potential inhibitory mechanisms of flavonoids against SARS-CoV-2 infection and their significant immunomodulatory activities. The data were mapped and compared to elect major flavonoids with a promising role in the
\end{abstract}

M. M. Alzaabi · A. A. El-Keblawy

Department of Applied Biology, College of Science, University of Sharjah, P.O. Box 27272, Sharjah, United Arab Emirates

M. M. Alzaabi · A. A. El-Keblawy

Research Institutes of Science and Engineering, University of Sharjah, P.O. Box 27272, Sharjah, United Arab Emirates

R. Hamdy · N. S. Ashmawy · A. M. Hamoda ·

S. S. M. Soliman

Research Institute for Medical and Health Sciences, University of Sharjah, P.O. Box 27272, Sharjah, United Arab Emirates

R. Hamdy

Faculty of Pharmacy, Zagazig University, Zagazig 44519,

Egypt current pandemic. Further, we have linked the global existence of flavonoids in medicinal plants and their role in protection against COVID-19. Computational analysis predicted that flavonoids can exhibit potential inhibitory activity against SARS-CoV-2 by binding to essential viral targets required in virus entry and/ or replication. Flavonoids also showed excellent immunomodulatory and anti-inflammatory activities including the inhibition of various inflammatory cytokines. Further, flavonoids showed significant ability to reduce the exacerbation of COVID-19 in the case of obesity via promoting lipids metabolism. Moreover, flavonoids exhibit a high safety profile,

\section{N. S. Ashmawy}

Department of Pharmacognosy, Faculty of Pharmacy, Ain Shams University, 11566 Abbassia, Cairo, Egypt

A. M. Hamoda

Department of Pharmacognosy, Faculty of Pharmacy, Assiut University, Assiut, Egypt

A. M. Hamoda

College of Medicine, University of Sharjah,

P.O. Box 27272, Sharjah, United Arab Emirates

F. Alkhayat · N. N. Khademi - S. M.

A. Al Joud · S. S. M. Soliman ( $₫)$

College of Pharmacy, University of Sharjah,

P.O. Box 27272, Sharjah, United Arab Emirates

e-mail: ssoliman@sharjah.ac.ae 
suitable bioavailability, and no significant adverse effects. For instance, plants rich in flavonoids are globally distributed and can offer great protection from COVID-19. The data described in this study strongly highlighted that flavonoids particularly quercetin and luteolin can exhibit promising multi-target activity against SARS-CoV-2, which promote their use in the current and expected future outbreaks. Therefore, a regimen of flavonoid-rich plants can be recommended to supplement a sufficient amount of flavonoids for the protection and treatment from SARS-CoV-2 infection.

Keywords COVID-19 - SARS-CoV-2 - Flavonoids · Treatment $\cdot$ Immunomodulatory $\cdot$ Global distribution

$\begin{array}{ll}\text { Abbreviations } \\ \text { ACE2 } & \text { Angiotensin converting enzyme II } \\ \text { ADME } & \text { Absorption, distribution, metabolism, } \\ & \text { and excretion of a drug molecule } \\ \text { ALI } & \text { Acute lung injury } \\ \text { ARDS } & \text { Acute respiratory distress syndrome } \\ \text { CCL5 } & \text { Inflammatory chemokines } \\ \text { COVID-19 } & \text { Coronavirus disease-2019 } \\ \Delta \text { G } & \text { Binding energy } \\ \text { DCs } & \text { Dendritic cells } \\ \text { E protein } & \text { Envelope protein } \\ \text { ERK } & \text { Extracellular-signal regulated kinase } \\ & \text { pathway } \\ \text { I.P. } & \text { Intraperitoneal } \\ \text { C } 50 & \text { The concentration of drug required for } \\ & \text { 50\% inhibition } \\ \text { IL-6 } & \text { Interleukin-6 } \\ \text { LPH } & \text { Lactase phloridzin hydrolase } \\ \text { LPS } & \text { Lipopolysaccharides } \\ \text { M protein } & \text { Membrane glycoprotein } \\ \text { MED } & \text { Mediterranean } \\ \text { MERSCoV } & \text { Middle East respiratory syndrome } \\ & \text { coronavirus } \\ \text { M pro } & \text { Main protease } \\ \text { N protein } & \text { Nucleocapsid protein } \\ \text { NF- } 6 B & \text { Nuclear factor kappa B pathway } \\ \text { Nsps } & \text { Non-structural proteins } \\ \text { PDB } & \text { Protein data bank } \\ \text { PLpro } & \text { Papain-like protease } \\ \text { PD } & \text { Peptidase domain } \\ \text { RBD } & \text { Receptor binding domain } \\ \text { RdRp } & \text { RNA dependent RNA Polymerase } \\ & \end{array}$

SARS- Severe acute respiratory syndrome

CoV-2

SGLT1 Intestinal $\mathrm{Na}+$-dependent glucose co-transporter

Sprotein Spike protein

TMPRSS2 Type 2 transmembrane serine protease

TNF- $\alpha$ Tumor necrosis factor alpha

WHO World Health Organization

\section{Introduction}

On December 2019, a novel coronavirus outbreak was reported as a severe acute respiratory disease syndrome coronavirus 2 (SARS-CoV-2) (Rabi et al. 2020; Yang and Shen 2020). Early on January 12, 2020, the World Health Organization (WHO) announced an unprecedented pandemic outbreak of new discovered virus from the betacoronavirus family that has not been previously identified in human and was named 2019 novel coronavirus or " 2019 nCoV" (Chen et al. 2020b). Subsequently, on February 11, 2020, WHO announced the official name of the disease caused by 2019-nCoV as Coronavirus Disease 2019, which is abbreviated as COVID-19.

COVID-19 is the sixth CoV outbreak identified globally (WHO 2020). SARS-CoV-2 is closely related to SARS-CoV (Ge et al. 2013; Lau et al. 2005). In addition to COVID-19 outbreak, coronavirus has caused three zoonotic outbreaks within the last two decades that belong to betacoronavirus family (Boopathi et al. 2020). These include acute respiratory syndrome coronavirus (SARS-CoV), Middle East respiratory syndrome coronavirus (MERS-CoV) in China during the 2001 to 2003 period and from 2012 to 2015 in Saudi Arabia (Boopathi et al. 2020). SARSCoV-2 can develop severe complications including septic shock and multiple organ failure that may result in death especially in people at high risk including immunocompromised and those with underlying medical conditions such as cancers, diabetes, cardiovascular disease, and chronic respiratory diseases. The common disease symptoms of COVID-19 can include fever, cough, shortness of breath, and dyspnea, while in severe cases, SARS-CoV-2 infection can cause pneumonia, severe acute respiratory syndrome, organ failure, and death (Wang et al. 2020). 


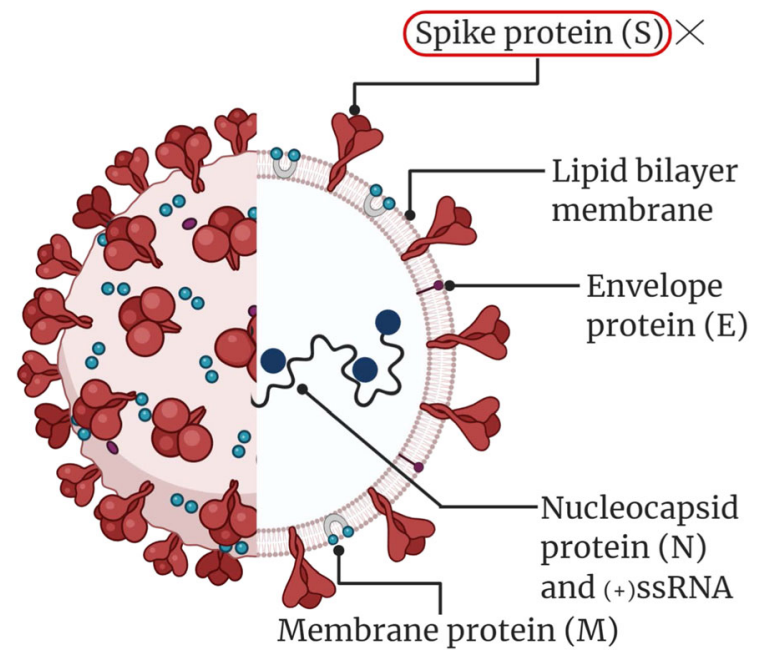

Fig. 1 Diagrammatic cartoon drawing of SARS-CoV-2 showing the main structural features of the virus. The red frame and cross sign indicated a critical therapeutic target

SARS-CoV-2 contains four essential proteins including membrane glycoprotein $(\mathrm{M})$, spike (S) protein, envelope $(\mathrm{E})$ protein and nucleocapsid $(\mathrm{N})$ protein (Fig. 1) (Mahmoud et al. 2020). The first three proteins are embedded in a lipid bilayer, while the $\mathrm{N}$ protein coats the single-stranded positive-sense viral RNA (Jin et al. 2020). E protein plays a vital role in the virus assembly (Gupta et al. 2020), whereas M protein is the most abundant protein that is considered as a central organizer for coronavirus assembly (Boopathi et al. 2020). The $\mathrm{N}$ protein plays an important role in virus transcription and translation (Boopathi et al. 2020). There are several non-structural proteins (nsps) such as nsp12 for RNA-dependent-RNA polymerase (RdRp), nsp3 for papain-like protease (PLpro) and nsp5 for the viral main protease $\left(\mathrm{M}^{\text {pro }}\right.$ ) (Dai et al. 2020). The $S$ protein is located on the surface of the virus (Dai et al. 2020) and facilitates the SARS-CoV-2 entry into the human cell by binding to the host cell surface receptor angiotensin converting enzyme-2 (ACE-2) (Kirchdoerfer et al. 2016; Simmons et al. 2013). The $S$ protein is composed of two main functional domains, the $\mathrm{N}$-terminal $\mathrm{S} 1$ and $\mathrm{C}$-terminal S2 subunits (Beniac et al. 2006). The S1 contains receptor binding domain (RBD) that is necessary for the binding with the host cell receptors (Wong et al. 2004), and S2 mediates the membrane fusion (Walls et al. 2020). SARS-CoV-2 RBD has 10-20-fold higher
ACE-2 binding affinity than SARS-CoV RBD (Kirchdoerfer et al. 2018; Wrapp et al. 2020).

Coronavirus infective cycle can be summarized in Fig. 2 (Al-Horani et al. 2020). The S protein of the virus first binds to ACE-2 receptor (Astuti and Ysrafil 2020), which is proteolytically activated by cleavage with human type 2 transmembrane serine (TMPRSS2) (Russo et al. 2020) into two subunits, S1 and S2 (Astuti and Ysrafil 2020), which allows the virus entery (Yang and Shen 2020). Subsequently, the viral particle is uncoated to deliver the positive sense single-stranded RNA [(+)ssRNA] into the cytoplasm (Liu et al. 2020). RNA-dependent RNA polymerase (RdRp) is an essential enzyme required for viral replication and transcription (Oostra et al. 2007).

The outbreak due to SARS-CoV-2 infection creates devastating social, economic, political, and global health problems, while a number of vaccines and medications were either approved or in clinical studies (Wang et al. 2020). Recently, several vaccine platforms were entered into the clinical evaluation (Le et al. 2020). These include (i) Nucleic acid vaccines as mRNA-based-vaccines such as Moderna (Mahase 2020), BioNTech/Pfizer (Müller et al. 2021), CureVac/ Bayer (Rosales-Mendoza et al. 2020), and Inovio as DNA-based vaccines (Calina et al. 2020); (ii) Viral vector vaccines as Ad vector (ChAdOx1) developed by AstraZeneca (Wise 2021), Johnson Johnson vaccine developed by Janssen Vaccines (Livingston et al. 2021) and Sputnik V (Jones and Roy 2021) developed by Gamaleya Research Institute of Epidemiology and Microbiology; (iii) Inactivated virus as Sinovac vaccine (Palacios et al. 2020) developed by China Sinovac biotech company; (iv) Antigen-based vaccine EpiVacCorona that was developed by the Vector Institute (Ryzhikov et al. 2021). On the other hand, the treatments suggested for COVID-19 are limited to those either still in clinical trials such as favipiravir (Pilkington et al. 2020), ribavirin (Khalili et al. 2020), lopinavir-ritonavir (Dalerba et al. 2020), emetine (Choy et al. 2020), hydroxychloroquine (Chen et al. 2020a), methionine (Zhang et al. 2020), homoharringtonine and ivermectin (Elgazzar et al. 2020) or initially approved by U.S. FDA such as remdesivir (Beigel et al. 2020). Furthermore, CR3022 monoclonal antibody with binding affinity to the RBD of SARS-CoV-2 S protein was suggested as a therapeutic approach (Lee et al. 2020). IFN-I with an established role in suppression 


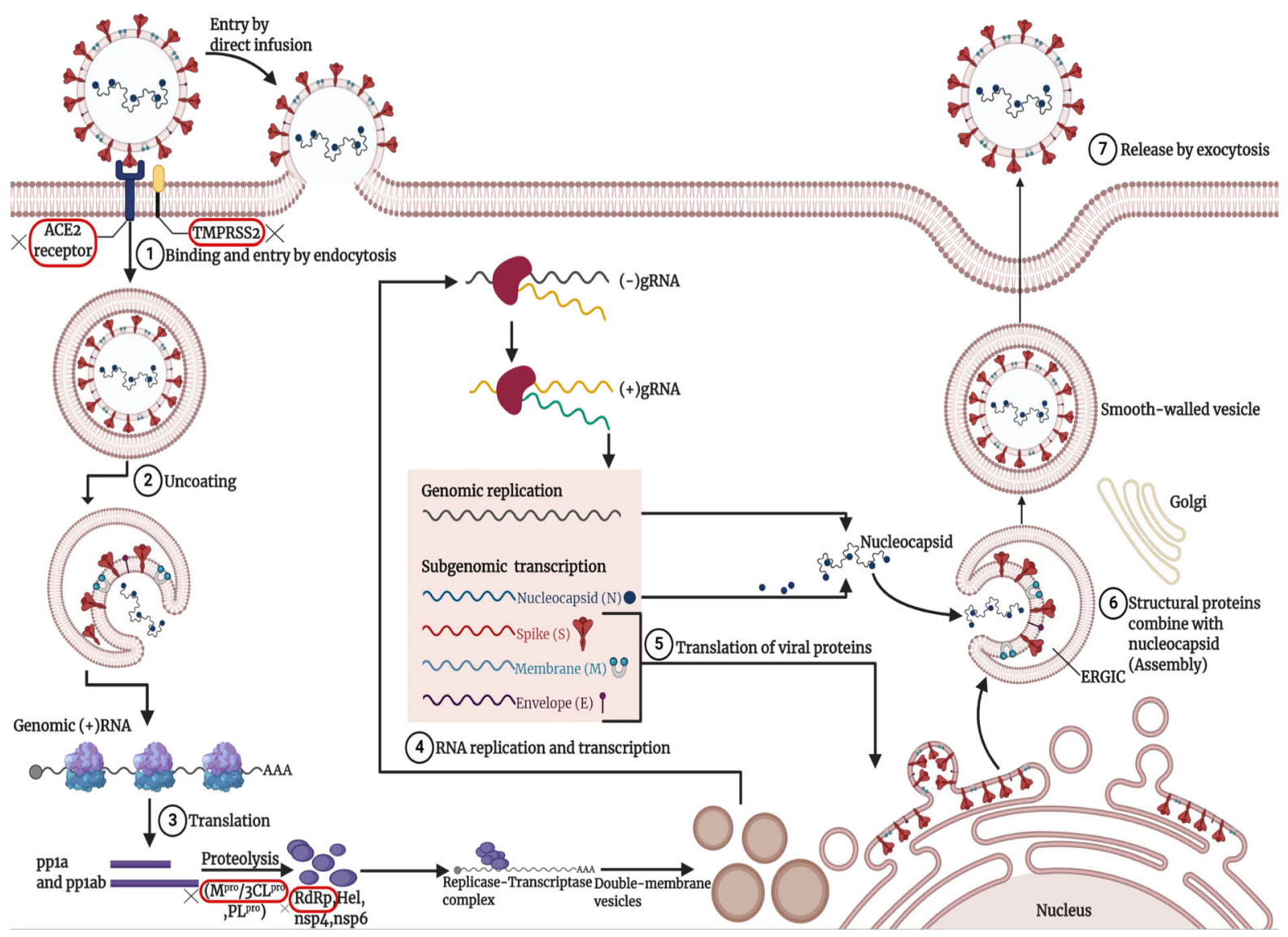

Fig. 2 Diagrammatic drawing of the virus life cycle and critical therapeutic targets indicated in red frame and cross sign

and treatment of SARS-CoV, MERS-CoV and SARSCoV-2 infections was also suggested (Lee and Shin 2020).

Natural products can provide effective antiviral activity against SARS-CoV-2. For instance, flavonoids are phenolic phytochemicals (Solnier and Fladerer 2020) that show various important biological activities including antiviral, antioxidant, and antiinflammatory activities (Krych and Gebicka 2013; Ragab et al. 2014; Tian et al. 2013; Zhang et al. 2015). Flavonoids are widely distributed in medicinal plants, vegetables, fruits, nuts, seeds, tea, honey, and propolis (Ahmad et al. 2015; Yahia 2019). This review highlights the importance of flavonoids as treatment and prophylaxis against SARS-CoV-2, their predicted therapeutic targets and proposed regimen supplements.

\section{Flavonoids-mediated inhibition mechanisms of SARS-CoV-2: in silico study}

All flavonoids identified in silico as potential inhibitors to SARS-CoV-2 are listed in Fig. 3 and Table 1. It has been identified that $\mathrm{M}^{\text {pro }}$ is necessarily required for the replication of SARS-CoV (Yang et al. 2003). Further analysis showed that $\mathrm{M}^{\text {pro }}$ of SARS-CoV-2 and SARS-CoV are very similar (Tahir Ul Qamar et al. 2020). Therefore, targeting $M^{\text {pro }}$ is of great therapeutic value. A molecular docking study revealed that naringenin can bind to $\mathrm{M}^{\text {pro }}$ by forming $\mathrm{H}$-bond with the amino acids of the $\mathrm{M}^{\text {pro }}$ active site, indicating the inhibition capability of naringenin to SARS-CoV-2 $\mathrm{M}^{\text {pro }}$ (Khaerunnisa et al. 2020). Recent studies showed that hesperidin has an inhibitory activity against SARS-CoV-2 by binding to SARS-CoV-2 $\mathrm{M}^{\text {pro }}$, the receptor-binding domain of $S$ protein (RBD-S) and the peptidase domain of ACE-2 (PD-ACE-2) (Adem et al. 2020; Tallei et al. 2020; Utomo et al. 2020). An in 
Fig. 3 Major flavonoids identified with potential inhibition activity against SARS-CoV-2<smiles>Nc1cc(O)c2c(c1)O[C@@H](c1ccc(O)cc1)CC2=O</smiles><smiles>COc1ccc([C@H]2CC(=O)c3c(O)cc(OC(O)C(O)C(O)C(O)COC4OC(C)C(O)C(O)C4O)cc3O2)cc1O</smiles><smiles>C=C(C=CC(=O)O)[C@H]1CC(=O)c2c(O)cc(OC(OC(OC3OC(C)C(O)C(O)C3O)C(O)C(C)O)C(O)C(C)O)cc2O1</smiles><smiles>COCCOCCO</smiles>

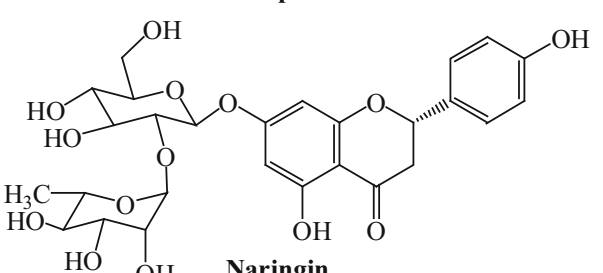<smiles>O=C1CCOc2cc(O)cc(O)c21</smiles><smiles>CCc1ccc(O)cc1</smiles><smiles>C1CCCC1</smiles> 
Table 1 Flavonoid classes identified in silico as potential inhibitors to SARS-CoV-2 targets

\begin{tabular}{|c|c|c|c|}
\hline $\begin{array}{l}\text { Flavonoid class and } \\
\text { compound }\end{array}$ & $\begin{array}{l}\text { SARS-CoV-2 } \\
\text { target }\end{array}$ & Binding energy $(\Delta \mathrm{G})$ & References \\
\hline \multicolumn{4}{|l|}{ Flavanones } \\
\hline Naringenin & $\mathrm{M}^{\mathrm{pro}}, \mathrm{ACE}-2$ & $-7.89\left(\mathrm{M}^{\mathrm{pro}}\right),-6.05(\mathrm{ACE}-2)$ & (Cheng et al. 2020; Khaerunnisa et al. 2020) \\
\hline $\begin{array}{l}\text { Hesperidin } \\
\text { Neohesperidin }\end{array}$ & $\begin{array}{l}\mathrm{M}^{\text {pro }}, \mathrm{ACE}-2, \\
\quad \mathrm{RBD}-\mathrm{S}\end{array}$ & $\begin{array}{l}-8.3\left(\mathrm{M}^{\mathrm{pro}}\right),-9.50(\mathrm{ACE}-2) \\
-10.4(\mathrm{RBD}-\mathrm{S})\end{array}$ & $\begin{array}{l}\text { (Adem et al. 2020; Ngwa et al. 2020; Tallei et al. } \\
\text { 2020; Utomo et al. 2020) }\end{array}$ \\
\hline Naringin & $\begin{array}{l}\text { TMPRSS2 } \\
\text { TMPRSS2 }\end{array}$ & $\begin{array}{l}-8.82 \\
-7.57\end{array}$ & $\begin{array}{l}\text { (Chikhale et al. 2020) } \\
\text { (Chikhale et al. 2020) }\end{array}$ \\
\hline Anthocyanidins & & & \\
\hline $\begin{array}{l}\text { Cyanidin } \\
\text { Flavanols }\end{array}$ & $\mathrm{M}^{\mathrm{pro}}, \mathrm{RdRp}$ & $-7.9\left(\mathrm{M}^{\mathrm{pro}}\right),-8.8(\mathrm{RdRp})$ & (Pendyala and Patras 2020) \\
\hline Catechin & $\mathrm{M}^{\text {pro }}$ & -7.24 & (Khaerunnisa et al. 2020) \\
\hline $\begin{array}{l}\text { Epigallocatechin } \\
\text { Flavones }\end{array}$ & $\mathrm{M}^{\mathrm{pro}}$ & -6.67 & (Khaerunnisa et al. 2020) \\
\hline Apigenin & $\mathbf{M}^{\text {pro }}$ & -7.83 & (Khaerunnisa et al. 2020) \\
\hline Luteolin & $\mathrm{M}^{\mathrm{pro}}, \mathrm{ACE}-2, \mathrm{~S}$ & $-8.17\left(\mathrm{M}^{\mathrm{pro}}\right)$ & (Khaerunnisa et al. 2020) \\
\hline $\begin{array}{l}\text { Caflanone } \\
\text { Isoflavones }\end{array}$ & ACE2 & -7.9 & (Ngwa et al. 2020) \\
\hline $\begin{array}{l}\text { Genistein } \\
\text { Flavonols }\end{array}$ & $\mathrm{M}^{\mathrm{pro}}, \mathrm{RdRp}$ & $-7.6\left(\mathrm{M}^{\mathrm{pro}}\right),-8.6(\mathrm{RdRp})$ & (Pendyala and Patras 2020) \\
\hline $\begin{array}{l}\text { Quercetin } \\
\text { Kaempferol } \\
\text { Myricetin } \\
\text { Icariin } \\
\text { Linebacker }\end{array}$ & $\begin{array}{l}\mathrm{M}^{\text {pro }}, \text { TMPRSS2, } \\
\quad \text { ACE-2, S } \\
\text { M }^{\text {pro }}, \text { TMPRSS2 } \\
\text { ACE-2, } \\
\quad \text { TMPRSS2 } \\
\text { TMPRSS2 } \\
\text { ACE-2 }\end{array}$ & $\begin{array}{l}-8.47\left(\mathrm{M}^{\mathrm{pro}}\right),-6.90(\mathrm{TMPRSS} 2) \\
-8.58 \\
-8.9(\mathrm{ACE}-2),-4.83 \\
(\mathrm{TMPRSS} 2) \\
-8.83 \\
-9.2\end{array}$ & $\begin{array}{l}\text { (Chikhale et al. 2020; Khaerunnisa et al. 2020; } \\
\text { Sekiou et al. 2020) } \\
\text { (Khaerunnisa et al. 2020) } \\
\text { (Chikhale et al. 2020; Ngwa et al. 2020) } \\
\text { (Chikhale et al. 2020) } \\
\text { (Ngwa et al. 2020) }\end{array}$ \\
\hline
\end{tabular}

$\mathrm{M}^{\text {pro }}$ following a virtual screening of 2030 natural compounds (Xu et al. 2020).

A well-identified therapeutic strategy is by targeting the ACE-2 receptor. Due to the high similarities of the receptor-binding domain of $\mathrm{S}$ protein between SARS-CoV and SARS-CoV-2, both viruses showed excellent ability to bind to human ACE-2 receptor (Wan et al. 2020). Molecular docking studies were performed to investigate the binding affinity of several flavonoids to ACE-2 and/ or S protein. It has been shown that hesperetin, myricetin, linebacker and caflanone showed excellent binding affinity to $\mathrm{S}$ protein, helicase and ACE-2 receptor and hence can block the entry of the virus (Ngwa et al. 2020). Another study showed that naringenin has low binding energy to the ACE-2 receptor, indicating a high binding affinity to ACE-2 (Cheng et al. 2020). A computational study revealed that baicalin flavonoid showed excellent binding affinity to $\mathrm{S}$ protein compared to abacavir and hydroxychloroquine. Baicalin was also reported with antiviral activity against other viral infections (Pandey et al. 2021).

Human TMPRSS2 is a critical protease used by the virus for its activation via $S$ protein cleavage (Hoffmann et al. 2020). A computational study was performed and the results showed that neohesperidin, myricitrin, quercitrin, naringin, and icariin flavonoids have a strong binding affinity towards TMPRSS2 (Chikhale et al. 2020). A comprehensive computational study also indicated that silybin may have a high binding affinity to TMPRSS2 that is required for viral entry, and chrysin with outstanding binding affinity to the $\mathrm{M}^{\text {pro }}$ of SARS-CoV, MERS-CoV and SARS-CoV- 
2. Chrysin also inhibited the interaction of ACE-2 with the S protein of SARS-CoV-2 (Jha et al. 2020).

\section{Flavonoids-mediated inhibition mechanisms of SARS-CoV-2: in vitro study}

Quercetin has displayed significant inhibition activity against SARS-CoV $\mathrm{M}^{\text {pro }}$, expressed in Pichia pastoris, at $\mathrm{IC}_{50} 73 \mu \mathrm{M}$ (Nguyen et al. 2012). Quercetin showed anti-SARS-CoV-2 and immunomodulatory activities particularly when co-administered with vitamin C. Both exert synergistic effect and can be employed for prophylaxis in high-risk populations (Colunga Biancatelli et al. 2020). Similarly, herbacetin, rhoifolin and pectolinarin flavonoids can efficiently block the enzymatic activity of SARS-CoV $M^{\text {pro }}$ (Jo et al. 2020). Fractionation-based anti-papain protease activity of the methanolic extract of Paulownia tomentosa fruits identified different geranylated flavonoid derivatives as potent inhibitory activity to SARS-CoV papain protease (Báez-Santos et al. 2015).

The aforementioned data indicated that several flavonoids showed potential inhibition activity to SARS-CoV-2 by possible targeting of essential proteins in the viral life cycle. However, a limited number of flavonoids have been tested in vitro. Therefore, it is important to validate the computational study by performing an appropriate biological activity.

\section{Immunomodulatory and anti-inflammatory activities of flavonoids}

Severe cases of COVID-19 have been characterized by developing cytokine storm (Mahmudpour et al. 2020), a life-threatening complication associated with the acute respiratory distress syndrome (ARDS). Those cases may represent more than 33\% of COVID-19 hospitalized patients and $\sim 40 \%$ mortality rates (Tzotzos et al. 2020). Comparative analysis of blood samples showed that severe COVID-19 patients have higher plasma levels of GCSF, IP10, MCP1, MIP1A, IL-2, IL-6, IL-7, IL-10 and TNF- $\alpha$, indicative of high serum levels of pro-inflammatory cytokines (Cheng et al. 2020). Inhibition of hyperinflammatory response and regulation of immune responses is an important strategy to attenuate cytokine storm (Mahmudpour et al. 2020). Interestingly, flavonoids exhibit significant immunomodulatory and anti-inflammatory activities (Hodek et al. 2002; Hosseinzade et al. 2019), which can be employed as a possible treatment or amelioration of complicated COVID-19 symptoms. Below are the most important flavonoids classes that can be employed as immunomodulators (Table 2).

Flavanones: naringenin and hesperetin

Naringenin has been shown to exhibit promising immunomodulatory activity by reducing the severity of inflammatory responses (Tutunchi et al. 2020). A study that examined the effect of naringenin on rats' lungs, exposed to benzo[ $\alpha]$ pyrene, showed that naringenin exerted a protective effect by reducing the proinflammatory cytokines through inhibition of NF- $\kappa B$ (Ali et al. 2017), which results in reducing the expression of COX-2 and restoring the normal histology of the rat lungs (Ali et al. 2017). Another study showed that the administration of naringenin can significantly reduce the expression of NF- $\kappa \mathrm{B}$, iNOS and TNF- $\alpha$ in rats' lungs with sepsis (Fouad et al. 2016). Besides, naringenin markedly reduced the inflammatory cytokine production, pulmonary oedema, IL-6 and MPO activity (Fouad et al. 2016). Current therapies shorten the duration of illness but do not improve survival (Coz Yataco and Simpson 2020). Therefore, naringenin could be employed as an immunomodulatory agent in SARS-CoV-2 infection, following further investigations.

An in vitro study on mouse adipocytes showed that hesperetin and naringenin downregulate the expression of TNF- $\alpha$ inflammatory mediator. This resulted in the inhibition of ERK and NF- $\kappa$ B pathways, leading to inhibition of IL-6 transcription (Yoshida et al. 2010). Further research study on rats suffering from acute lung injury indicated that hesperetin increases the expression of peroxisome proliferators activated receptor gamma. Subsequently, it inhibits the NF- $\kappa B$ pathway, results in a significant reduction in the production of inflammatory cytokines including IL-6, IL-1 $\beta$, and TNF- $\alpha$ (Ma et al. 2015). Pre-treatment of acute lung injury (ALI) mice model by hesperetin caused a protective effect against pulmonary inflammation, meanwhile, hesperetin decreases the TNF- $\alpha$ and IL-6 expression (Ye et al. 2019). 
Table 2 Immunomodulatory and anti-inflammatory effects of various flavonoid classes

\begin{tabular}{|c|c|c|}
\hline Flavonoid & Immunomodulatory mechanism & References \\
\hline \multicolumn{3}{|l|}{ Flavanones } \\
\hline Naringenin & $\begin{array}{l}\text { Inhibits ERK and NF- } \kappa \text { B pathways, reduces COX-2, iNOS and TNF- } \alpha \\
\text { expression and reduces IL- } 6 \text { and MPO activity }\end{array}$ & $\begin{array}{l}\text { (Ali et al. 2017; Fouad et al. 2016; Yoshida } \\
\text { et al. 2010) }\end{array}$ \\
\hline Hesperetin & $\begin{array}{l}\text { Inhibits ERK and NF- } \kappa B \text { pathways, works as PPAR- } \gamma \text { agonist and } \\
\text { reduces IL- } 6 \text {, IL- } 1 \beta \text { and TNF- } \alpha \text { expression }\end{array}$ & $\begin{array}{l}\text { (Ma et al. 2015; Ye et al. 2019; Yoshida } \\
\text { et al. 2010) }\end{array}$ \\
\hline \multicolumn{3}{|l|}{ Flavonoles } \\
\hline Quercetin & $\begin{array}{l}\text { Regulates Th1/Th2 balance, inhibits tyrosine phosphorylation of EGFR } \\
\text { and NF- } \mathrm{B} \text { pathways and binds to aryl hydrocarbon receptor, and } \\
\text { impairs T-cell activation }\end{array}$ & $\begin{array}{l}\text { (Michalski et al. 2020; Park et al. 2009; } \\
\text { Rogerio et al. 2010; Yang et al. 2012) }\end{array}$ \\
\hline Fisetin & $\begin{array}{l}\text { Inhibits NF- } \kappa \mathrm{B} \text { and phosphorylation of ERK1/2 pathways, inhibits PKC- } \\
\delta \text { activity, COX-2 and prostaglandin E2 production and decreases IL-6, } \\
\text { IL-8, TNF- } \alpha, \text { CCL5 and MPC1 levels }\end{array}$ & (Lee et al. 2018; Peng et al. 2018) \\
\hline \multicolumn{3}{|l|}{ Flavones } \\
\hline Chrysin & $\begin{array}{l}\text { Inhibits NF- } \kappa \text { B pathway, works as PPAR- } \gamma \text { agonist, inhibits COX- } 2 \text { and } \\
\text { MPO activity, inhibits TNF- } \alpha \text {, IL- } 1 \beta \text {, IL- } 8 \text { and iNOS levels, stimulates } \\
\text { macrophage lysosomal activity, and inhibits the production of nitric } \\
\text { oxide }\end{array}$ & $\begin{array}{l}\text { (Sassi et al. 2017; Shen et al. 2015; Zeinali } \\
\text { et al. 2017) }\end{array}$ \\
\hline Apigenin & Inhibits IL-6, CCL5, ICAM1and VCAM1 & (Zhang et al. 2014) \\
\hline Luteolin & 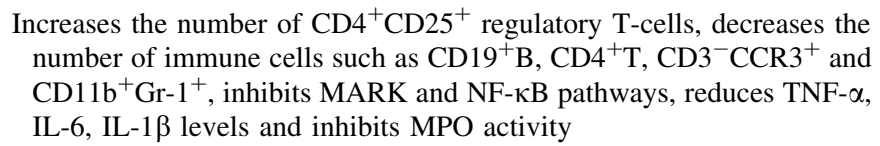 & $\begin{array}{l}\text { (Kim et al. 2018; Kuo et al. 2011; Liu et al. } \\
\text { 2018) }\end{array}$ \\
\hline Caflanone & Inhibits microsomal prostaglandin E synthase 1 and 5-lipoxyganse & (Erridge et al. 2020) \\
\hline
\end{tabular}

Flavonols: quercetin and fisetin

Quercetin caused inhibition of OVA-induced airway inflammation and leukocyte recruitment to the airways in murine mice asthma model (Park et al. 2009). Quercetin can regulate the Th1/ Th2 balance (Park et al. 2009). Oral administration of quercetin-loaded micro-emulsion in murine asthma model showed similar effects to dexamethasone, indicated by a significant reduction in mucus production in the lungs (Rogerio et al. 2010). Quercetin micro-emulsion also showed inhibition of NF- $\kappa \mathrm{B}$ and selectively restrains Th2 cytokine (Rogerio et al. 2010). COVID-19 patients showed elevated MUC1 and MUC5AC mucin protein levels (Lu et al. 2020). Interestingly, quercetin inhibits tyrosine phosphorylation of EGFR and NF- $\kappa B$ pathways resulted in the suppression of mucin synthesis in rat lungs and reduction of MUC5AC in human airway epithelial NCI-H292 cells, and hence it reduces the mucus production and difficulty in breathing (Yang et al. 2012). Furthermore, quercetin exerts immunomodulatory effects on human dendritic cells (DCs) by direct the binding of aryl hydrocarbon receptor to CD83 promoter causing down expression of CD83 (Michalski et al. 2020). This impairs T-cell activation and migration of matured DCs (Michalski et al. 2020).

Fisetin showed significant anti-inflammatory and immunomodulatory effect. Pre-treatment of IL-1 $\beta$ stimulated human lung epithelial cells with fisetin caused inhibition of COX-2 and reduction in IL-6, IL8 , TNF- $\alpha$, CCL5, MCP1, and prostaglandin E2 (Peng et al. 2018). Fisetin also downregulates the NF- $\kappa B$ pathway and interferes with the phosphorylation of proteins in the ERK1/2 pathway, leading to a significant reduction in ICAM1 expression, which is involved in monocyte adhesion (Peng et al. 2018). Fisetin negatively modulates the PKC- $\delta$ activity in human airway epithelial cells, which is essential for the activation of the TNF- $\alpha / \mathrm{IKK} / \mathrm{NF}-\kappa \mathrm{B}$ signalling cascade (Lee et al. 2018). Inhibition of PKC- $\delta$ significantly reduces the TNF- $\alpha$-induced IL- 8 levels. Interestingly, fisetin has a similar effect to the broad protein kinase inhibitor, Staurosporine, hence it can be 
employed as a potential immunomodulator in lung inflammation (Lee et al. 2018).

Flavones: Chrysin, apigenin, luteolin and caflanone

An extensive overview of immunomodulatory and anti-inflammatory effects of chrysin concluded that chrysin has multiple mechanisms. Chrysin can suppress NF- $\kappa \mathrm{B}$, which controls the expression of genes encoding the pro-inflammatory cytokines, COX-2 and iNOS (Zeinali et al. 2017). Besides, it is an agonist to PPAR- $\gamma$, which downregulates COX-2, MPO and iNOS (Zeinali et al. 2017). Pre-treatment of mice, exposed to cigarette smoking to induce inflammation of airway epithelial cells, with chrysin ameliorated the inflammation by suppressing the release of TNF- $\alpha$, IL$1 \beta$, IL-8, and MPO expression in the lung tissue (Shen et al. 2015). Chrysin also inhibits ERK and p38 phosphorylation (Shen et al. 2015). In another study to analyse the immunomodulatory effect of chrysin on rat peritoneal macrophages, chrysin stimulates macrophage lysosomal activity, which involved in killing and digesting the microbial pathogens and inhibited the production of nitric oxide (Sassi et al. 2017). Docking study indicated that chrysin can bind weakly to COX-1, but strongly to COX-2 enzymes, indicating that it has relative selectivity to $\mathrm{COX}-2$, and hence reduces the possibility of undesired GIT adverse effects (Rauf et al. 2015). Similarly, pre-treatment of pre-inflamed human macrophage with apigenin showed significant inhibition of IL-6 secretion and stability of IL-6 mRNA (Zhang et al. 2014). Apigenin did not inhibit only the pro-inflammatory cytokines, but also the inflammatory chemokines (CCL5) and adhesion molecules (ICAM1 and VCAM1) (Zhang et al. 2014).

Luteolin significantly increases the number of $\mathrm{CD} 4+\mathrm{CD} 25+$ regulatory T-cells in murine splenic CD4 + - T cells that were stimulated by anti-CD3/ anti-CD28 (Kim et al. 2018). Luteolin also presented immunomodulatory activity by decreasing the number of immune cells such as CD19 + B, CD4 + T, CD3$\mathrm{CCR} 3+$, and $\mathrm{CD} 11 \mathrm{~b}+\mathrm{Gr}-1+$ in the lung of inflamed airway mouse model (Kim et al. 2018). Luteolin also inhibits the NF- $\kappa \mathrm{B}$ pathway, reduces TNF- $\alpha$, IL- 6 , IL- $1 \beta$ levels and significantly inhibits MPO activity (Liu et al. 2018). Luteolin also showed a protective effect against lipopolysaccharides (LPS)- induced ALI mice model by inhibition of MAPK pathways, leading to inhibition of the NF- $\kappa$ B pathway and IKB degradation (Kuo et al. 2011). Caflanone possesses anti-inflammatory activity by inhibition of microsomal prostaglandin E synthase 1 and 5-lipoxygenase (Erridge et al. 2020).

The data described here indicated the significant immunomodulatory activities of many flavonoids, while their antiviral activities still need to be validated to complement their potential inhibition activity against SARS-CoV-2.

\section{Potential anti-SARS-CoV-2 activity of flavonoids in the case of complication by obesity}

A case study of COVID-19 patients in Shenzhen, China concluded that obesity increases the risk of developing severe COVID-19 (Cai et al. 2020). Obesity may exacerbate infection by SARS-CoV-2 and can result in severe COVID-19 cases. An explanation for that can be attributed to the higher expression of ACE-2 in adipose tissues located in the lung (Jia et al. 2020). Furthermore, it has been shown that host lipids represent a critical factor in SARS-CoV-2 infection and completion of the life cycle (Alketbi et al., 2021).

Different studies indicated that flavonoids can be employed to reduce the body fat mass by generating a feeling of satiety by reducing the food intake (Panda and Shinde 2017). Flavonoid-rich foods can target the lipid-regulating enzymes and prevents lipid accumulation (Wu et al. 2010). Furthermore, flavonoids can reduce the weight of abdominal adipose tissue due to their effect on decreasing the hepatic and plasma triglyceride (TG) levels by regulating the rate-limiting enzymes involved in the fatty acid synthesis and oxidation in the liver (Kamisoyama et al. 2008). Interestingly, consuming tea catechin, a flavan-3-ol, is good for the suppression of high-fat diet-induced obesity via activation of lipid metabolism in the liver (Murase et al. 2002). Collectively, a diet rich in flavonoids can reduce the exacerbation of COVID-19 by reducing body fat mass, a factor that can increase SARS-CoV-2 load. 
Table 3 Flavonoids $\mathrm{LD}_{50}$

\begin{tabular}{lll}
\hline Flavonoids & $\mathrm{LD}_{50}$ & References \\
\hline Naringenin & $>5000 \mathrm{mg} / \mathrm{kg}($ Oral $)$ & (Ortiz-Andrade et al. 2008) \\
Hesperidin & $>2000 \mathrm{mg} / \mathrm{kg}($ Oral) & (Bigoniya and Singh 2014) \\
Quercetin & $>160 \mathrm{mg} / \mathrm{kg}($ Oral) & (Sullivan et al. 1951) \\
Chrysin & $=4350 \mathrm{mg} / \mathrm{kg}($ Oral) & (Yao et al. 2019) \\
Apigenin & $>5000 \mathrm{mg} / \mathrm{kg}$ (I.P.) & (Zarei et al. 2017) \\
Luteolin & $>5000 \mathrm{mg} / \mathrm{kg}($ Oral) & (Liming 1985) \\
\hline
\end{tabular}

\section{Safety and efficacy of flavonoids}

Generally, flavonoids exhibit a high safety profile and $\mathrm{LD}_{50}$ as indicated in Table 3. It has been shown that oral administration of quercetin possesses no significant mutagenicity/ genotoxicity effects on mice and rats (Harwood et al. 2007). Quercetin is a welltolerated compound and did not induce any adverse effects when administered orally and intravenously up to $1 \mathrm{~g} /$ day and at $\sim 10.8 \mathrm{mg} / \mathrm{kg}$ to human, respectively (Ferry et al. 1996; Shoskes et al. 1999). Similarly, oral administration of $450 \mathrm{mg}$ citrus dry extract containing at least $90 \%$ of catechin of total polyphenols and at least $20 \%$ of naringenin of total flavanones to healthy overweight individuals did not induce any adverse effects (Dallas et al. 2014). No adverse effects have been observed in patients with muscular dystrophy when administered Flavomega, an oral dosage form that contains roots of Scutellaria and dry extract of green tea as a source of flavonoids (Sitzia et al. 2019). Intraperitoneal administration of apigenin, up to $100 \mathrm{mg} / \mathrm{kg}$ in mice does not induce any toxic effects (Viola et al. 1995).

The extent of absorption, distribution, metabolism and excretion of flavonoids are affecting its efficacy (Miranda et al. 2012). Different sources of flavonoids have different absorption and bioavailability (Ross and Kasum 2002). Sugar moiety attached to aglycone plays a major role in flavonoid absorption and bioavailability (Hollman 2009). Since most flavonoids found in diets are $\beta$-glycosides, they can be absorbed in two ways at the small intestine either by lactase phloridzin hydrolase (LPH) or intestinal $\mathrm{Na}^{+}$- dependent glucose co-transporter (SGLT1) (Hollman 2009). Although flavonoids have poor oral absorption and bioavailability (Ross and Kasum 2002; Thilakarathna and Rupasinghe 2013) because of the hydrophilic nature of the flavonoid glycosides (Hollman 2009), the aglycones have a strong affinity to plasma; indicating their activity at low concentration (Xiao and Kai 2012). Moreover, flavonoids undergo extensive metabolism in the intestine and liver leading to the formation of conjugated forms, which is increasing the ability of their elimination (Thilakarathna and Rupasinghe 2013). Therefore, the low bioavailability of flavonoids may hinder their oral administration (Thilakarathna and Rupasinghe 2013). On the other side, several approaches were employed to improve the bioavailability of the flavonoids including nanoformulations to improve the intestinal absorption, and microemulsions or complexing with $\beta$-cyclodextrin to improve the bioavailability (Thilakarathna and Rupasinghe 2013). Flavonoids encapsulated in smart nanoparticles with the ability to target ACE-2 receptors were administered by inhalation to mice to enhance their bioavailability and efficacy (Ngwa et al. 2020). Nano-emulsion and nano-liposomal formulations not only enhance the oral bioavailability of naringenin but also enhance the therapeutic efficacy and stability (Zobeiri et al. 2018). Fisetin encapsulation in nano-liposomal formulation enhanced the bioavailability by 47 folds when compared to free fisetin (Seguin et al. 2013).

\section{Potential flavonoids with multi-targeting activity}

According to the aforementioned data, one can conclude that flavonoids such as naringenin, apigenin, luteolin and quercetin can exert multiple activities as indicated in Table 4. Molecular docking studies of these flavonoids were further tested to validate the binding affinity to major targets including $\mathrm{M}^{\text {pro }}$, ACE2 and TMPRSS2 (Table 4 and Figs. 4, 5, 6). The 3D structures of flavonoids and 3D crystal structures of proteins were downloaded and saved in PDBQT format using Chimera software. The binding modes between the elected flavonoids and target proteins 
Table 4 Potential flavonoids with dual activity against viral and human proteins

\begin{tabular}{|c|c|c|c|c|c|}
\hline \multirow[t]{3}{*}{ Flavonoid } & \multicolumn{4}{|c|}{ Targets binding energy (Kcal/mol) } & \multirow[t]{3}{*}{ Immunomodulatory activity } \\
\hline & \multicolumn{2}{|l|}{ Host Target } & \multicolumn{2}{|c|}{ Viral Target } & \\
\hline & ACE-2 receptor & TMPRSS2 & $\mathrm{M}^{\text {pro }}$ & $\operatorname{RdRp}$ & \\
\hline Quercetin & -9.1 & -7.7 & -7.0 & -8.5 & Anti-inflammatory \\
\hline Luteolin & -8.9 & -7.4 & -7.1 & -8.3 & Reduces IL-6 expression \\
\hline Apigenin & -8.5 & -7.7 & -6.7 & -7.8 & Inhibits IL-6 \\
\hline Naringenin & -8.5 & -7.3 & -6.8 & -7.7 & Reduces IL-6 expression \\
\hline Enalaprilat & -8.8 & & & & \\
\hline Camostat & & -7.7 & & & \\
\hline GC376 & & & -6.0 & & \\
\hline Remedisivir & & & & -8.9 & \\
\hline
\end{tabular}

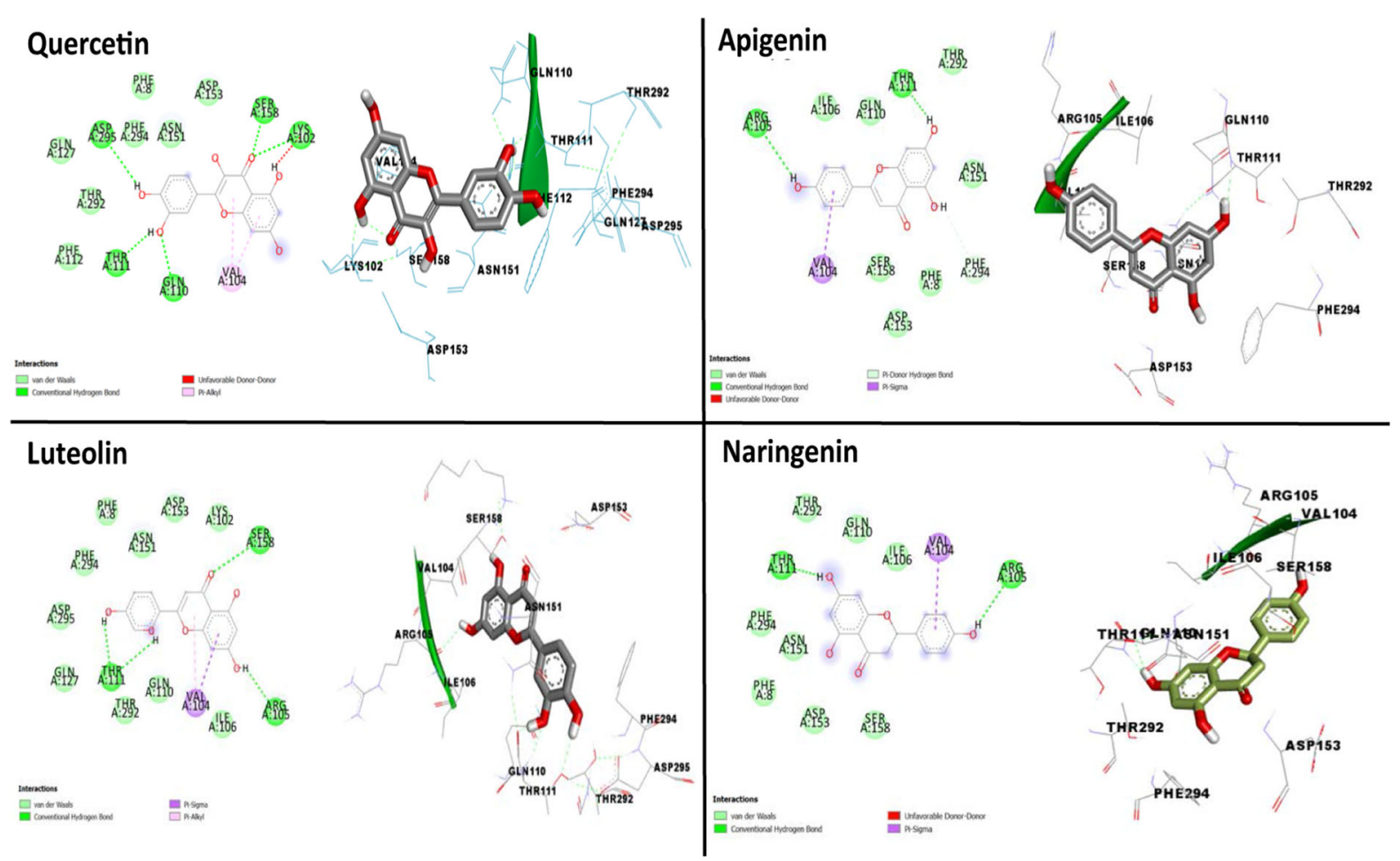

Fig. 4 Binding affinity of flavonoids to $\mathrm{M}^{\text {pro }}$

were performed using PyRx Autodock binding engines. Flavonoids were screened against $\mathbf{M}^{\text {pro }}$ (PDB: 6LU7), TMPRSS2 (PDB: 2OQ5), ACE-2 (PDB: 1R4L), and RdRp (PDB: 7BV2). The twodimensional interaction with different amino acids was presented using Discovery Studio software.

The results indicated that quercetin and luteolin showed good binding energy with the binding pocket of $\mathrm{M}^{\text {pro }}$ (PDB: 6UL7) lower than that of GC376 inhibitor, indicating the formation of a stable complex. The superiority of quercetin and luteolin binding is due to the vicinal hydroxyl groups that act as metal chelators for the target enzyme (Fig. 4). Similarly, quercetin and luteolin showed good binding affinity to ACE-2 receptor with lower binding energy in comparison to enalaprilat (Fig. 5). Furthermore, quercetin and apigenin showed binding affinity to TMPRSS2 similar to Camostat (Fig. 6). The displayed binding 


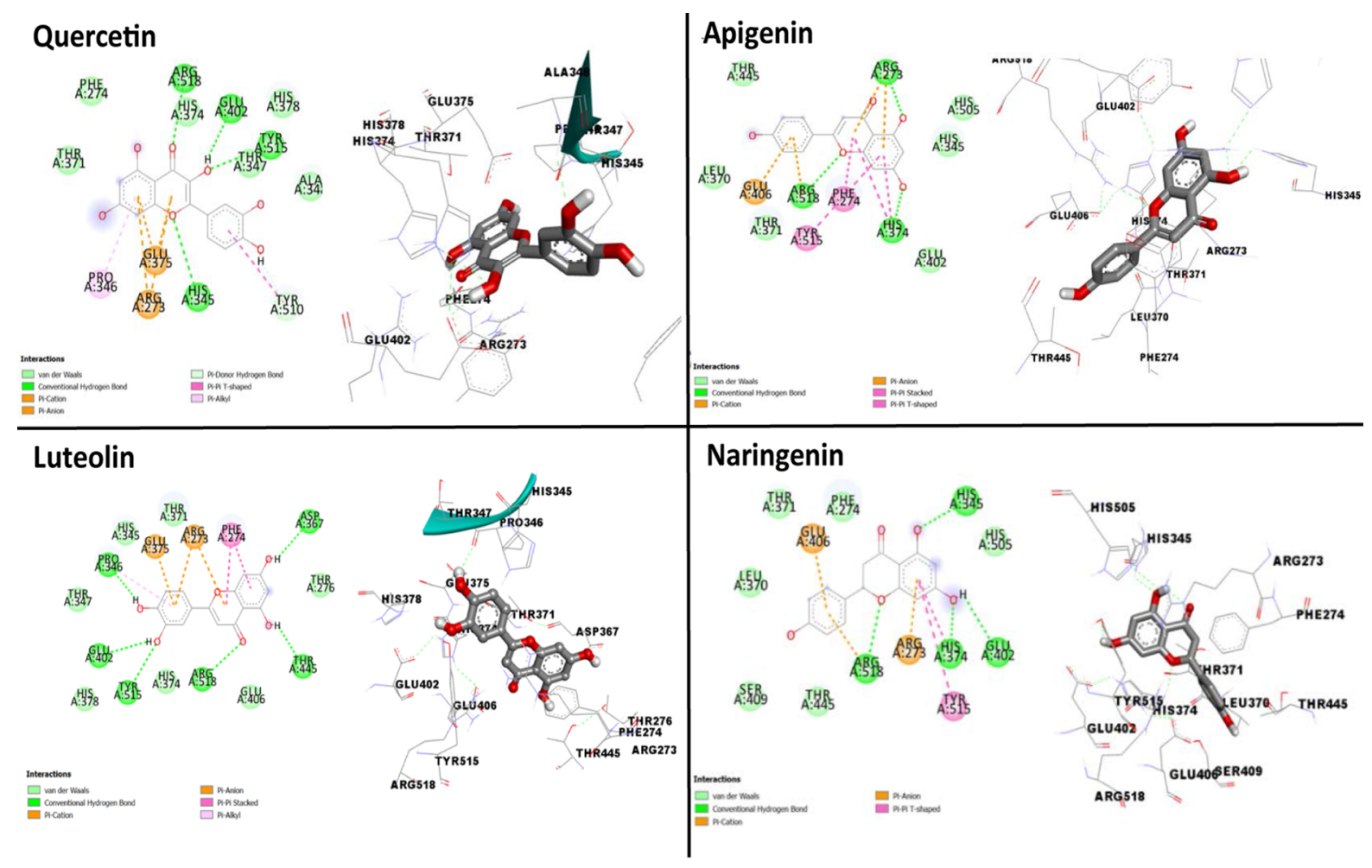

Fig. 5 Binding affinity of elected flavonoids to ACE-2 receptor

affinity of flavonoids is mainly owing to the hydrophobicity of the aromatic rings and the hydrophilic hydroxyl groups. However, they all showed lower binding affinity to RdRp when compared to remdesivir (Table 4).

The ADME properties were further screened using a Swiss-ADME server (Daina et al. 2017). The elected flavonoids comply with the Lipinski rule of 5 $(\operatorname{HBD}<5, \mathrm{HBA}<10, \operatorname{Logp}<5$, and Mwt $<500)$. The compounds showed good gastrointestinal adsorption, good solubility with $\log \mathrm{s}<4$ and hence good bioavailability. Notably, they were safe and non-toxic (Fig. 7 and Table 5).

The results obtained highlight the importance of flavonoids as lead for the development of novel antiviral drugs. These flavonoids particularly quercetin and luteolin should be employed for further clinical investigations as a promising therapy against SARSCoV-2.

\section{Potential sources of flavonoids and environmental impact}

Flavonoids are a large and diverse group of phenolic secondary metabolites widely distributed in plants. It has been reported that the richest sources of flavonols (Quercetin, kaempferol, and myricetin) are yellow onions (up to $1.2 \mathrm{~g} / \mathrm{kg}$ fresh wt) and curly kale (up to $0.6 \mathrm{~g} / \mathrm{kg}$ fresh wt) (Manach et al. 2004). Other sources with moderate levels of flavonols $(0.1-0.225 \mathrm{~g} / \mathrm{kg}$ fresh wt) are leeks, cherry tomato, broccoli, and blueberries (Manach et al. 2004). Furthermore, other sources with lower concentrations of flavonols were reported in black Curran, apricot, apple, red apple, beans, black grape, tomato, black and green tea (Manach et al. 2004). Flavones (apigenin and luteolin) present in parsley, celery, capsicum, and pepper. Flavanones such as hesperetin, naringenin, and eriodictyol are rich in tomatoes, orange, grapefruit, and lemon (Manach et al. 2004). Several other flavonoids have been identified in many wild plants such as Atriplex hortensis, Betula alba, Brassica rapa, Ephedra alata, Hibiscus sabdariffa, Juniperus communis, 


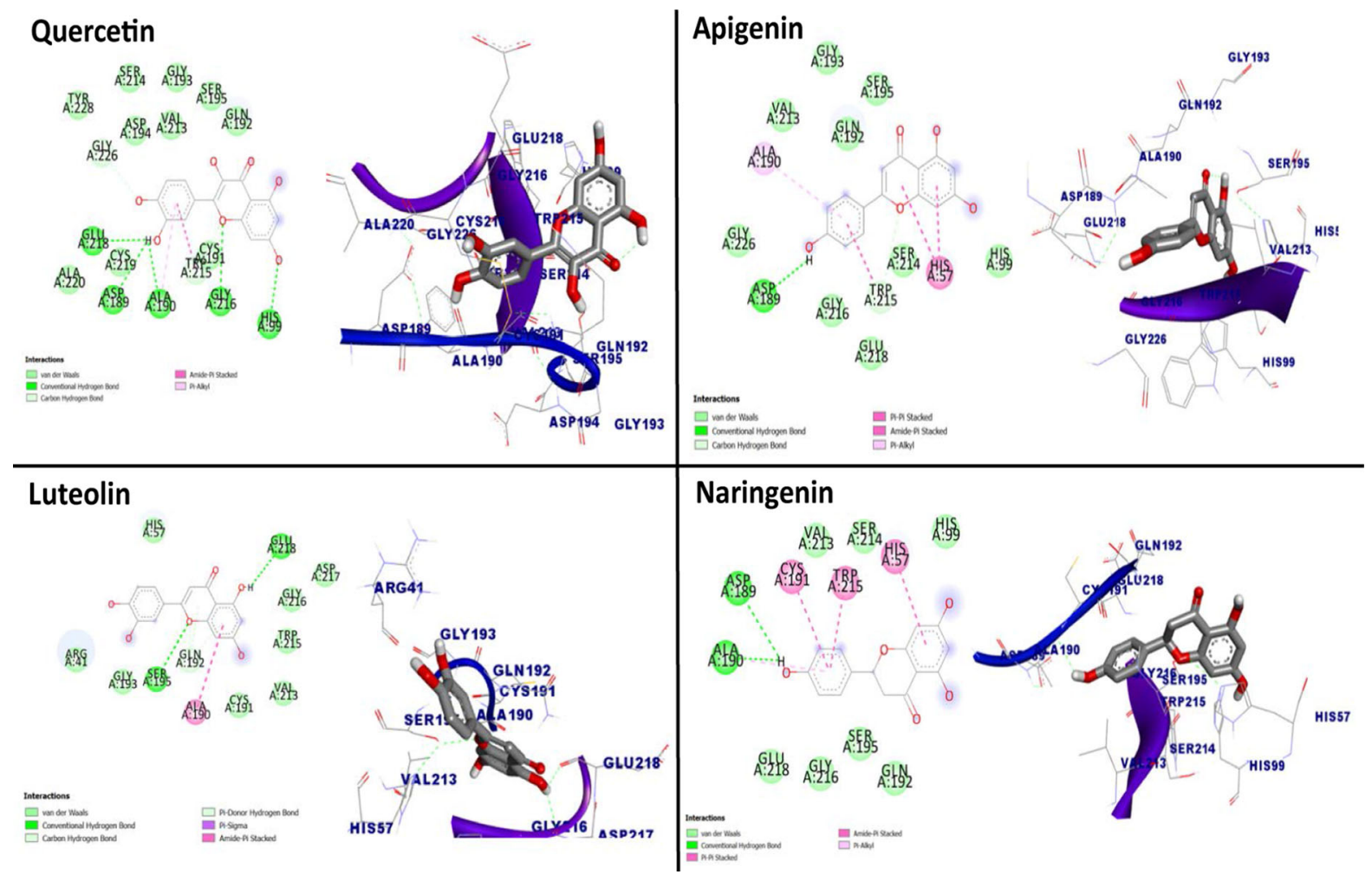

Fig. 6 Binding affinity of elected flavonoids to TMPRSS2
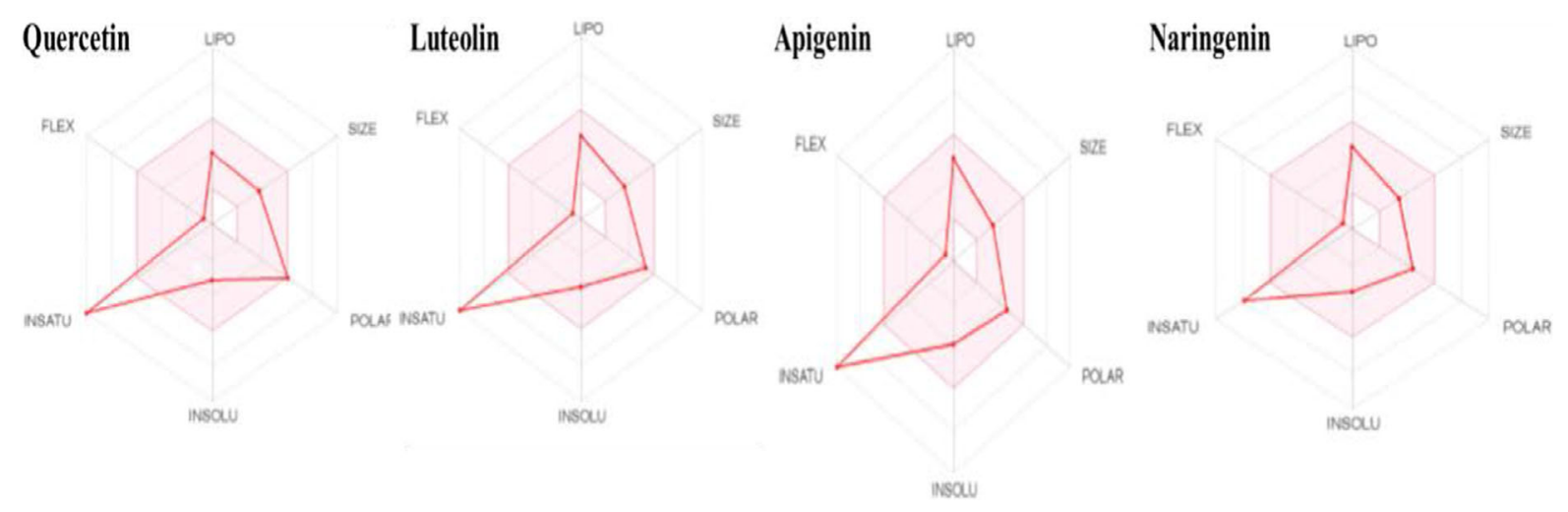

Fig. 7 Bioavailability radar of flavonoids. The figures indicated the acceptable pharmacokinetics and within conformity range. The pink area indicates preferred properties range

Antirrhinum majus, and Artemisia campestris (AlSnafi 2020).

The types and concentration of flavonoids in plants are changed in response to the duration and frequency of environmental conditions associated with different geographic regions including the temperature, light duration, intensity and quality (Oh et al. 2009). Abouleish et al. 2020, showed that environmental factors can significantly affect the concentration and types of plant phytochemicals with potential activity against SARS-CoV-2 (Abouleish 2020). They have described the impact of the season, temperature, and drought on the yield and composition of plant phytochemicals including flavonoids. Besides, other environmental factors including the time of harvest, processing, and storage can affect the flavonoid 
Table 5 Predication of ADME properties of elected flavonoids

\begin{tabular}{lllll}
\hline Models & Quercetin & Luteolin & Apigenin & Naringenin \\
\hline TPSA & 131.6 & 111.13 & 90.9 & 90.9 \\
Molecular formulae & $\mathrm{C}_{15} \mathrm{H}_{10} \mathrm{O}_{7}$ & $\mathrm{C}_{15} \mathrm{H}_{10} \mathrm{O}_{6}$ & $\mathrm{C}_{15} \mathrm{H}_{10} \mathrm{O}_{5}$ & $\mathrm{C}_{15} \mathrm{H}_{10} \mathrm{O}_{5}$ \\
Molecular weight & 302.24 & 286.24 & 270.24 & 272.25 \\
HBA & 7 & 6 & 5 & 5 \\
HBD & 5 & 4 & 3 & 3 \\
Log p & 1.63 & 1.86 & 1.89 & 1.75 \\
GI Absorption & High & High & High & High \\
Bioavailability score & 0.55 & 0.55 & 0.55 & 0.55 \\
P-glycoprotein Substrate & Non-substrate & Non-substrate & Non-substrate & Non-substrate \\
BBB permeability & No & No & No & No \\
CYP2C19 inhibitor & No & No & No & No \\
CYP1A2 inhibitor & Yes & Yes & Yes & Yes \\
Lead likeness violations & 0 & 0 & 0 & 0 \\
Synthetic accessibility & 3.23 & 3.02 & 2.96 & 3.01 \\
No of rotatable H bond & 1 & 1 & 1 & 1 \\
ESOL solubility & Soluble & Soluble & Soluble & Soluble \\
Solubility (mg/mL) & 0.211 & 0.0563 & 0.0307 & 0.0874 \\
Log s & -3.16 & -3.71 & -3.94 & -3.49 \\
\hline & & & & \\
\hline
\end{tabular}

contents in medicinal plants (El-Keblawy et al. 2017; Manach et al. 2004). Therefore, assessing the impact of environmental conditions on plant flavonoids can help in the selection of the most suitable flavonoid-rich plants per geographical area (Sehlakgwe et al. 2020).

The most common and richest sources with several types of flavonoids for human intake are citrus and black and green teas (Manach et al. 2004). The intake of these plants was recommended as a therapy for COVID-19. Several investigators have indicated that environmental factors prevailing during the growth and development of citrus (Zandalinas et al. 2017) and tea (Table 6) can affect the types and accumulation of different flavonoids.

\section{Global intake of flavonoids}

The intake of flavonoids differs from a country to another. This is mainly due to the difference in the type and amount of food rich in flavonoids taken in each country (Table 7 and Fig. 8). The worldwide consumption of flavonoids ranges between 150-600 mg/day expressed as aglycones present in

Table 6 Effect of environmental factors on the flavonoid contents in tea leaves (Camellia sinensis)

\begin{tabular}{llll}
\hline Region/country & Environmental condition & Flavonoid content & References \\
\hline Jeju Island, South Korea & High temperature & Low & (Lee et al. 2010) \\
Malawi & High temperature & Low & (Owuor et al. 2008) \\
Phoenix Mountain, China & High altitude & High & (Chen et al. 2010) \\
Phoenix Mountain, China & Autumn growing season & High & (Chen et al. 2010) \\
Australia & Warm growing season & High & (Yao et al. 2005) \\
Seogwipo Si, Republic of Korea & High light intensity & High & (Ku et al. 2010) \\
Barcelona, Spain & Drought & High & (Hernández et al. 2006) \\
Anhui, China & High temperature & High & (Wang et al. 2012) \\
Anhui, China & Drought & High & (Wang et al. 2012) \\
\hline
\end{tabular}


Table 7 Intake of total flavonoids in representative countries

\begin{tabular}{lllll}
\hline Country & Intake (mg/day) & Main source & Major class & Reference \\
\hline Australia & 225 & Black tea & Flavanols & (Johannot and Somerset 2006) \\
Spain & 443 & Fruits & PA & (Tresserra-Rimbau et al. 2013) \\
Italy & 364 & Fruits & PA & (Vitale et al. 2018) \\
France & 436 & Fruits, tea, red wine & PA & (Perez-Jimenez et al. 2011) \\
Finland & 209 & Berries, fruit & PA & (Ovaskainen et al. 2008a, b) \\
Poland & 898 & Tea, cocoa, apples & Flavanols & (Grosso et al. 2014) \\
United Kingdom & 1000 & Tea & Flavanols, PA & (Tresserra-Rimbau et al. 2013) \\
US & 203 & Tea & Flavanols, PA & (Xiao et al. 2014) \\
Mexico & 235 & Fruits and orange & PA & (Zamora-Ros et al. 2018) \\
Brazil & 54.6 & Citrus fruits and beans & Flavanones & (Miranda et al. 2016) \\
China & 225 & Soy, pome fruit & Flavanols & (Zhang et al. 2014) \\
Korea & 318 & Fruit, tofu, onions & PA & (Jun et al. 2016) \\
Iran & 1652 & Vegetables, fruits & Flavanols & (Sohrab et al. 2013) \\
MED & 449 & Fruits & PA & (Zamora-Ros et al. 2016) \\
Non-MED & 522 & Fruits-black tea & PA & (Zamora-Ros et al. 2016) \\
\hline
\end{tabular}

MED = Mediterranean countries; Non-MED = Non-Mediterranean countries; PA = Proanthocyanidins

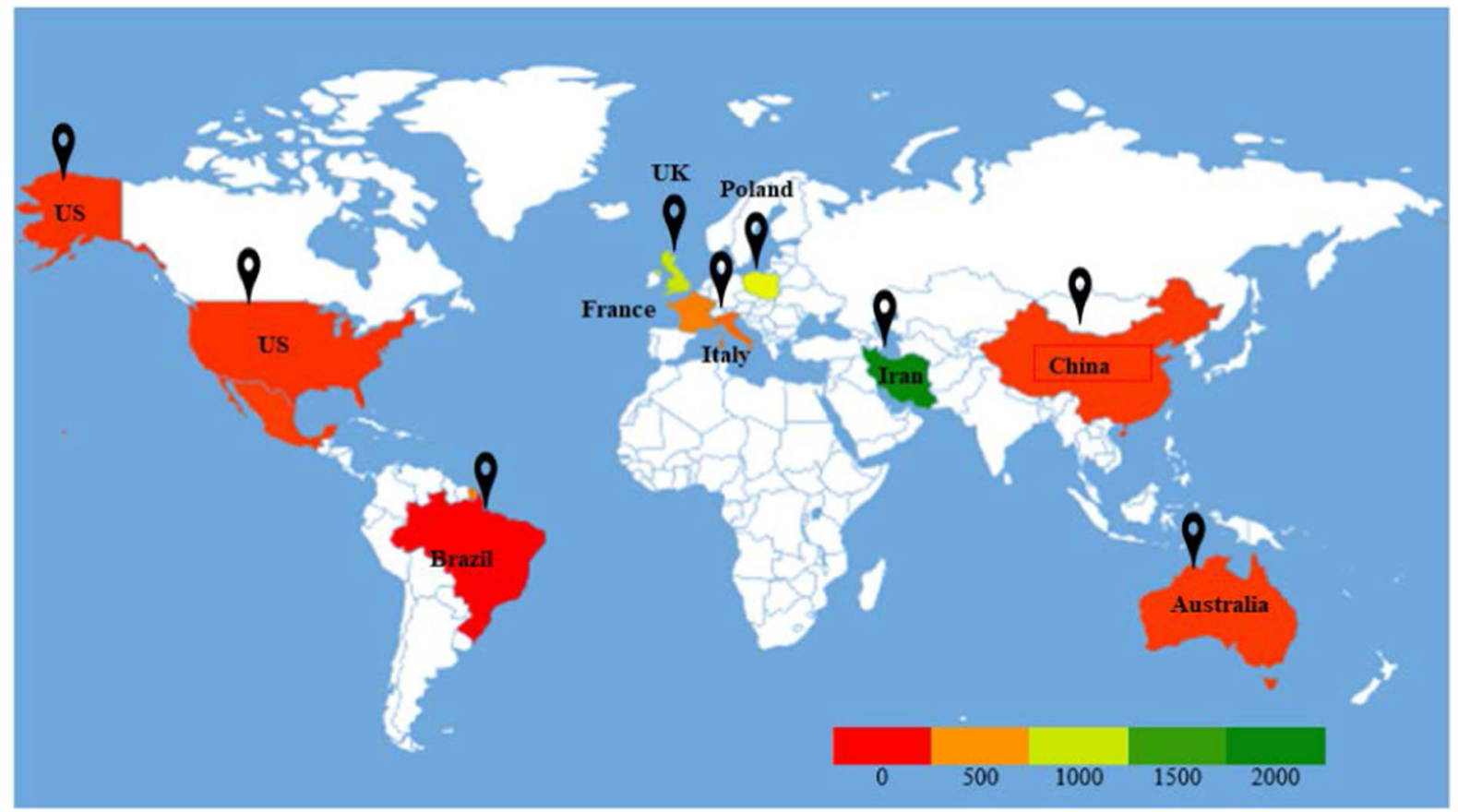

Fig. 8 Global heat map indicated the consumption of flavonoid-rich foods in representative countries. The heat map was generated by reporting the consumption of flavonoids per country (ElDohaji et al. 2020)

black tea(Zamora-Ros et al. 2016). This is varied between populations according to the black tea consumption levels and various dietary patterns. The intake of flavonoids varies greatly by geographical region (Tresserra-Rimbau et al. 2013). The intake of total flavonoids in European countries ranges between 
250-400 mg/day, which is lower than in non-Mediterranean (MED, northern European) countries (350-600 mg/day). This can be attributed to the higher intake of tea in non-MED countries relative to MED countries (Tresserra-Rimbau et al. 2013). In Mediterranean countries, like Spain, the major polyphenols source in the diet is the fruits and coffee, but the factor that mainly differentiates them from other countries is the consumption of polyphenolics from olive oil and olives(Tresserra-Rimbau et al. 2013). Because of the conventional tea community, the highest overall flavonoids consumption in Europe is in the UK ( $\sim 500$ to $>1000 \mathrm{mg} /$ day) (Zamora-Ros et al. 2016). On the other hand, Eastern European countries such as Poland showed a high intake of total flavonoids ( $600 \mathrm{mg} /$ day) due to the high consumption of tea (Zamora-Ros et al. 2013), while the southern regions such as France has an intermediate intake of total flavonoids (Witkowska et al. 2015). The intake of total flavonoids in Scandinavian countries, such as Finland, is $200-250 \mathrm{mg} /$ day, which is lower than in MED countries, because of lower tea and fruit consumption (Ovaskainen et al. 2008a, b).

Australia has a high intake of total flavonoids (650-700 mg/day), because of high tea consumption. Black tea consumption contributes to at least $75 \%$ of total polyphenols (Kent et al. 2015). The mean intake of total flavonoids in the US ranges from 250 to $400 \mathrm{mg} /$ day (Kim et al. 2016). Although tea consumption is not very high, tea is still the primary source of total flavonoids in the US, possibly due to the low fruit and vegetable consumption. In Mexico and Brazil, the consumption of total flavonoids is about 150 and $50 \mathrm{mg} /$ day, respectively. These countries are known globally as the lowest consumers of total flavonoids. Citrus in Mexico and beans in Brazil are the primary source of total flavonoids (Miranda et al. 2016).

In the Eastern Asian countries, such as China(Zhang et al. 2014), total flavonoids intake ranges between 65-225 mg/day (Zhang et al. 2014), since Chinese people drink green tea, but not black tea. The consumption of total flavonoids is significantly higher in South Korea (320 mg/day) (Chun et al. 2007). Soy and its derived products (the major food sources of isoflavones) are one of the most significant contributors to total flavonoids in East Asian countries, while proanthocyanidins and flavan-3-ol in South Korea and China are the most abundant flavonoids. Japan, China and South Korea depend on isoflavones as a source of flavonoids, because of their phytoestrogenic effects (Barnes 2004). On the other hand, the mean intake of total flavonoids in the Middle East was estimated at $1650 \mathrm{mg} /$ day (Sohrab et al. 2013). This is the world's highest cumulative consumption of flavonoids, which is attributed to the high consumption of black tea.

In summary, there is high variability in the total flavonoids intake between different countries. Those with high consumption of tea, especially black tea, are the populations with a higher intake of total flavonoids. Fruits are the primary food sources, and proanthocyanidins are the main contributors to total flavonoids. There is a need for more studies on the content of flavonoids in foods to enhance the existing data regarding the food composition and their role/ relation in fighting against pathogens including SARSCoV-2.

\section{Suggested regimen of globally existed flavonoid- rich plants}

Based on the aforementioned data described here for the possible use of flavonoids as a treatment and protection against SARS-CoV-2, we are suggesting a protective and treatment regimen made of easily accessible plants and globally distributed. For example, fresh parsley (Petroselinum crispum), raw wild rocket (Diplotaxis tenuifolia) and raw oranges are globally accessible vegetables and fruits. Interestingly, they contain significant amounts of flavonoids. Fresh parsley contains $215.45 \mathrm{mg} / 100 \mathrm{~g}$ apigenin and $1.09 \mathrm{mg} / 100 \mathrm{~g}$ luteolin, raw wild rocket contains $66.19 \mathrm{mg} / 100 \mathrm{~g}$ quercetin and raw orange contains $27.25 \mathrm{mg} / 100 \mathrm{~g}$ hesperetin and $15.32 \mathrm{mg} / 100 \mathrm{~g}$ naringenin (Haytowitz 2018). Therefore, a regimen made of oranges with $420 \mathrm{~g}$ total weight, $300 \mathrm{~g}$ fresh parsley and $300 \mathrm{~g}$ raw rocket per day would supplement a total of $\sim 1 \mathrm{~g}$ flavonoids sufficient for the protection and treatment of SARS-CoV-2 infection (Di Matteo et al. 2020). This suggested regimen is still under investigation and needs further confirmation by clinical trials on COVID-19 patients. Current clinical trials employing $1000 \mathrm{mg} /$ day of quercetin as a treatment and $500 \mathrm{mg} /$ day as prophylaxis against SARS-CoV-2 infection are in the investigation process (Di Matteo et al. 2020). 


\section{Conclusion}

Consumption of flavonoids and flavonoids-rich plants can be of significant importance for the prevention and treatment of SARS-CoV-2, while providing enough safety on the human body. In fact, flavonoids have been shown to exhibit potential inhibitory activity against critical viral targets, required to facilitate their entry and replication, including $\mathrm{M}^{\mathrm{pro}}$, RBD of the $\mathrm{S}$ protein, RdRp, in addition to the human ACE-2 receptor and TMPRSS2. Further, the immunomodulatory activity of flavonoids has been proven via the inhibition of various pro-inflammatory cytokines and pathways involved in inflammatory reactions. Furthermore, flavonoids can reduce the COVID-19 exacerbation via their significant effect on the body fat mass. Flavonoids promote the satiety effect and lipids metabolism. Based on the global existence of flavonoid-rich plants, a preventive safe regimen can be recommended against SARS-CoV-2 following further clinical investigations.

Acknowledgements The authors acknowledge the generous funding from Sandooq Al-Watan and University of Sharjah to SS.

Author contributions MA collected the data related to the global distribution of flavonoids. RH measure the binding efficiency of selected flavonoids against major viral targets. NA collected the data related to the global distribution of flavonoids and draw the global heatmap. $\mathrm{AH}$ helped on collecting the antiviral activity and immunomodulatory activity of flavonoids. FA, NK and SJ collected the data related to antiviral and immunomodulatory activity of flavonoids. AK collected the data related to the occurrence of flavonoids in medicinal plants available worldwide. SS develop the idea of the manuscript, designed the manuscript, and wrote the drat and final version of the manuscript.

\section{Declarations}

Conflict of interest All authors declared there is no financial interest.

\section{References}

Abouleish M, El-Keblawy A et al (2020) Importance of Environmental Factors on Production of ComputationallyDefined Natural Molecules against COVID-19 Pandemic. Curr Top Med Chem 20:1958-1961

Adem S, Eyupoglu, V, Sarfraz, I et al (2020) Identification of potent COVID-19 main protease $\left(\mathrm{M}^{\text {pro }}\right)$ inhibitors from natural polyphenols: an in silico strategy unveils a hope against CORONA. preprints.org.

Ahmad A, Kaleem M, Ahmed Z et al (2015) Therapeutic potential of flavonoids and their mechanism of action against microbial and viral infections-A review. Food Res Int 77:231-235

Al-Horani RA, Kar S, Aliter KF (2020) Potential anti-COVID19 therapeutics that block the early stage of the viral life cycle: structures, mechanisms, and clinical trials. Int J Mol Sci 21:5224

Ali R, Shahid A, Ali N et al (2017) Amelioration of Benzo[a]pyrene-induced oxidative stress and pulmonary toxicity by Naringenin in Wistar rats: a plausible role of COX-2 and NF-кB. Hum Exp Toxicol 36:349-364

Alketbi EH, Hamdy R, El-Kabalawy A et al (2021) Lipid-based therapies against SARS-CoV-2 infection. Rev Med Virol 2021:1-13

Al-Snafi AE (2020) Phenolics and flavonoids contents of medicinal plants, as natural ingredients for many therapeutic purposes- A review. IOSR J Pharm 10:42-81

Astuti I, Ysrafil (2020) Severe acute respiratory syndrome coronavirus 2 (SARS-CoV-2): an overview of viral structure and host response. Diabetes Metab Syndr 14:407-412

Báez-Santos YM, John SES, Mesecar AD (2015) The SARScoronavirus papain-like protease: structure, function and inhibition by designed antiviral compounds. Antiviral Res 115:21-38

Barnes S (2004) Soy isoflavones-phytoestrogens and what else? J NUTR 134:1225S-1228S

Beigel JH, Tomashek KM, Dodd LE et al (2020) Remdesivir for the treatment of Covid-19. N Engl J Med 383:1813-1826

Beniac DR, Andonov A, Grudeski E et al (2006) Architecture of the SARS coronavirus prefusion spike. Nat Struct Mol Biol 13:751-752

Bigoniya P, Singh K (2014) Ulcer protective potential of standardized hesperidin, a citrus flavonoid isolated from Citrus sinensis. Rev Bras Farmacogn 24:330-340

Boopathi S, Poma AB, Kolandaivel P (2020) Novel 2019 coronavirus structure, mechanism of action, antiviral drug promises and rule out against its treatment. J Biomol Struct Dyn. https://doi.org/10.1080/07391102.2020.1758788

Cai Q, Chen F, Wang T et al (2020) Obesity and COVID-19 severity in a designated hospital in Shenzhen. China Diabetes Care 43:1392

Calina D, Docea AO, Petrakis D et al (2020) Towards effective COVID-19 vaccines: updates, perspectives and challenges. Int J Mol Med 46:3-16

Chen YL, Duan J, Jiang YM et al (2010) Production, quality, and biological effects of oolong tea (Camellia sinensis). Food Rev Int 27:1-15

Chen Y, Liu Q, Guo D (2020) Emerging coronaviruses: Genome structure, replication, and pathogenesis. J Med Virol 92:418-423

Chen J, Liu D, Liu L et al (2020) A pilot study of hydroxychloroquine in treatment of patients with common coronavirus disease-19 (COVID-19). J Zhejiang Univ Sci 49:0-0

Cheng L, Zheng W, Li M et al (2020) Citrus fruits are rich in flavonoids for immunoregulation and potential targeting ACE2. Preprints 2020:2020020313

Chikhale RV, Gupta VK, Eldesoky GE et al (2020) Identification of potential anti-TMPRSS2 natural products through 
homology modelling, virtual screening and molecular dynamics simulation studies. J Biomol Struct Dyn. https:// doi.org/10.1080/07391102.2020.1798813

Choy K-T, Wong AY-L, Kaewpreedee P et al (2020) Remdesivir, lopinavir, emetine, and homoharringtonine inhibit SARS-CoV-2 replication in vitro. Antiviral Res 178:104786

Chun OK, Chung SJ, Song WO (2007) Estimated Dietary Flavonoid Intake and Major Food Sources of U.S. Adults J Nutr 137:1244-1252

Colunga Biancatelli RML, Berrill M, Catravas JD et al (2020) Quercetin and vitamin C: an experimental, synergistic therapy for the prevention and treatment of SARS-CoV-2 related disease (COVID-19). Front Immunol 11:1451

Coz Yataco AO, Simpson SQ (2020) Coronavirus disease 2019 sepsis: a nudge toward antibiotic stewardship. Chest 158:1833-1834

Dai W, Zhang B, Jiang XM et al (2020) Structure-based design of antiviral drug candidates targeting the SARS-CoV-2 main protease. Science 368:1331-1335

Daina A, Michielin O, Zoete V (2017) SwissADME: a free web tool to evaluate pharmacokinetics, drug-likeness and medicinal chemistry friendliness of small molecules. Sci Rep 7:42717

Dalerba P, Levin B, Thompson JL (2020) A trial of lopinavirritonavir in covid-19. N Engl J Med. https://doi.org/10. 1056/NEJMc2008043

Dallas C, Gerbi A, Elbez Y et al (2014) Clinical study to assess the efficacy and safety of a citrus polyphenolic extract of red orange, grapefruit, and orange (Sinetrol-XPur) on weight management and metabolic parameters in healthy overweight individuals. Phytother Res 28:212-218

Di Matteo G, Spano M, Grosso M et al (2020) Food and COVID19: preventive/co-therapeutic strategies explored by current clinical trials and in silico studies. Foods 9:1036

ElDohaji LM, Hamoda AM, Hamdy R et al (2020) Avicennia marina a natural reservoir of phytopharmaceuticals: curative power and platform of medicines. J Ethnopharmacol 263:113179

Elgazzar A, Hany, B, Youssef SA et al (2020) Efficacy and Safety of Ivermectin for Treatment and Prophylaxis of COVID-19 Pandemic. Research Square 2020, https://doi. org/10.21203/rs.3.rs-100956/v3

El-Keblawy A, Shabana HA, Navarro T et al (2017) Effect of maturation time on dormancy and germination of Citrullus colocynthis (Cucurbitaceae) seeds from the Arabian hyperarid deserts. BMC Plant Biol 17:1-10

Erridge S, Mangal N, Salazar O et al (2020) Cannflavins-from plant to patient: a scoping review. Fitoterapia 146:104712

Ferry DR, Smith A, Malkhandi J, Fyfe DW, deTakats PG, Anderson D, Baker J, Kerr DJ (1996) Phase I clinical trial of the flavonoid quercetin: pharmacokinetics and evidence for in vivo tyrosine kinase inhibition. Clin Cancer Res 2:659-668

Fouad AA, Albuali WH, Jresat I (2016) Protective effect of naringenin against lipopolysaccharide-induced acute lung injury in rats. Pharmacology 97:224-232

Ge XY, Li JL, Yang XL et al (2013) Isolation and characterization of a bat SARS-like coronavirus that uses the ACE2 receptor. Nature 503:535-538
Grosso G, Stepaniak U, Topor-Mądry R et al (2014) Estimated dietary intake and major food sources of polyphenols in the Polish arm of the HAPIEE study. Nutrition 30:1398-1403

Gupta MK, Vemula S, Donde R et al (2020) In-silico approaches to detect inhibitors of the human severe acute respiratory syndrome coronavirus envelope protein ion channel. J Biomol Struct Dyn. https://doi.org/10.1080/07391102. 2020.1751300

Harwood M, Danielewska-Nikiel B, Borzelleca JF et al (2007) A critical review of the data related to the safety of quercetin and lack of evidence of in vivo toxicity, including lack of genotoxic/carcinogenic properties. Food Chem Toxicol 45:2179-2205

Haytowitz DB, Wu X, Bhagwat S (2018) USDA Database for the flavanoid content of selected foods. Release 3(3):1-170

Hernández I, Alegre L, Munné-Bosch S (2006) Enhanced oxidation of flavan-3-ols and proanthocyanidin accumulation in water-stressed tea plants. Phytochemistry 67:1120-1126

Hodek P, Trefil P, Stiborová M (2002) Flavonoids-potent and versatile biologically active compounds interacting with cytochromes P450. Chem-Biol Interact 139:1-21

Hoffmann M, Kleine-Weber H, Schroeder S et al (2020) SARSCoV-2 Cell entry depends on ACE2 and TMPRSS2 and is blocked by a clinically proven protease inhibitor. Cell 181:271-280.e278

Hollman PCH (2009) Absorption, bioavailability, and metabolism of flavonoids. Pharm Biol 42:74-83

Hosseinzade A, Sadeghi O, Naghdipour Biregani A et al (2019) Immunomodulatory effects of flavonoids: possible induction of T CD4+ regulatory cells through suppression of mTOR pathway signaling activity. Front Immunol 10:51

Jha NK, Jeyaraman M, Rachamalla M et al (2021) Current understanding of novel coronavirus: Molecular pathogenesis, diagnosis, and treatment approaches. Immuno 1:30-66

Jia X, Yin, C, Lu, S et al (2020) Two Things about COVID-19 might need attention. Preprints 2020;2020020315

Jin Y, Yang H, Ji W et al (2020) Virology, epidemiology, pathogenesis, and control of COVID-19. Viruses 12:372

Jo S, Kim S, Shin DH et al (2020) Inhibition of SARS-CoV 3CL protease by flavonoids. J Enzyme Inhib Med Chem 35:145-151

Johannot L, Somerset SM (2006) Age-related variations in flavonoid intake and sources in the Australian population. Public Health Nutr 9:1045-1054

Jones I, Roy P (2021) Sputnik V COVID-19 vaccine candidate appears safe and effective. Lancet 397:642-643

Jun S, Shin S, Joung H (2016) Estimation of dietary flavonoid intake and major food sources of Korean adults. Br J Nutr 115:480-489

Kamisoyama H, Honda K, Tominaga Y et al (2008) Investigation of the anti-obesity action of licorice flavonoid oil in diet-induced obese rats. Biosci Biotechnol Biochem 72:3225-3231

Kent K, Charlton K, Russell J et al (2015) Estimation of flavonoid intake in older australians: secondary data analysis of the blue mountains eye study. J Nutr Gerontol Geriatr 34:388-398

Khaerunnisa S, Kurniawan, H, Awaluddin R et al (2020) Potential inhibitor of COVID-19 main protease ( $\mathrm{M}^{\text {pro }}$ ) from several medicinal plant compounds by molecular docking study. Preprints 2020:2020030226 
Khalili JS, Zhu H, Mak NSA et al (2020) Novel coronavirus treatment with ribavirin: groundwork for an evaluation concerning COVID-19. J Med Virol 92:740-746

Kim K, Vance TM, Chun OK (2016) Estimated intake and major food sources of flavonoids among US adults: changes between 1999-2002 and 2007-2010 in NHANES. Eur J Nutr 55:833-843

Kim SH, Saba E, Kim BK et al (2018) Luteolin attenuates airway inflammation by inducing the transition of CD4(+)CD25(-) to CD4(+)CD25(+) regulatory $\mathrm{T}$ cells. Eur J Pharmacol 820:53-64

Kirchdoerfer RN, Cottrell CA, Wang N et al (2016) Pre-fusion structure of a human coronavirus spike protein. Nature 531:118-121

Kirchdoerfer RN, Wang N, Pallesen J et al (2018) Stabilized coronavirus spikes are resistant to conformational changes induced by receptor recognition or proteolysis. Sci Rep 8:15701

Krych J, Gebicka L (2013) Catalase is inhibited by flavonoids. Int J Biol Macromol 58:148-153

Ku KM, Choi JN, Kim J et al (2010) Metabolomics analysis reveals the compositional differences of shade grown tea (Camellia sinensis L.). J Agric Food Chem 58:418-426

Kuo MY, Liao MF, Chen FL et al (2011) Luteolin attenuates the pulmonary inflammatory response involves abilities of antioxidation and inhibition of MAPK and NFKB pathways in mice with endotoxin-induced acute lung injury. Food Chem Toxicol 49:2660-2666

Lau SK, Woo PC, Li KS et al (2005) Severe acute respiratory syndrome coronavirus-like virus in Chinese horseshoe bats. Proc Natl Acad Sci U S A 102:14040-14045

Le TT, Andreadakis Z, Kumar A et al (2020) The COVID-19 vaccine development landscape. Nat Rev Drug Discov 19:305-306

Lee JS, Shin E-C (2020) The type I interferon response in COVID-19: implications for treatment. Nat Rev Immunol 20:585-586

Lee J, Lee B-J, Chung J et al (2010) Geographical and Climatic Dependencies of Green Tea (Camellia sinensis) Metabolites: A H-1 NMR-Based Metabolomics Study. J Agric Food Chem 58:10582-10589

Lee S, Ro H, In HJ et al (2018) Fisetin inhibits TNF-alpha/NFkappaB-induced IL-8 expression by targeting PKCdelta in human airway epithelial cells. Cytokine 108:247-254

Lee CY-P, Lin RT, Renia L et al (2020) Serological approaches for COVID-19: epidemiologic perspective on surveillance and control. Front Immunol 11:879

Liming D (1985) The influence of luteolin on experimental inflammatory model in rat. Acta Universitatis Medicinalis Anhui, p. 01

Liu B, Yu H, Baiyun R et al (2018) Protective effects of dietary luteolin against mercuric chloride-induced lung injury in mice: involvement of AKT/Nrf2 and NF- $\kappa \mathrm{B}$ pathways. Food Chem Toxicol 113:296-302

Liu T, Luo S, Libby P et al (2020) Cathepsin L-selective inhibitors: a potentially promising treatment for COVID-19 patients. Pharmacol Ther 213:107587-107587

Livingston EH, Malani PN, Creech CB (2021) The Johnson \& Johnson Vaccine for COVID-19. JAMA 325(15):1575-1575
Lu W, Liu X, Wang T et al (2020) Elevated MUC1 and MUC5AC mucin protein levels in airway mucus of critical ill COVID-19 patients. J Med Virol 93:582-584

Ma H, Feng X, Ding S (2015) Hesperetin attenuates ventilatorinduced acute lung injury through inhibition of NF- $\mathrm{KB}$ mediated inflammation. Eur J Pharmacol 769:333-341

Mahase E (2020) Covid-19: Moderna vaccine is nearly $95 \%$ effective, trial involving high risk and elderly people shows. BMJ. https://doi.org/10.1136/bmj.m4471

Mahmoud IS, Jarrar YB, Alshaer W et al (2020) SARS-CoV-2 entry in host cells-multiple targets for treatment and prevention. Biochimie 175:93-98

Mahmudpour M, Roozbeh J, Keshavarz M et al (2020) COVID19 cytokine storm: the anger of inflammation. Cytokine 133:155151

Manach C, Scalbert A, Morand C et al (2004) Polyphenols: food sources and bioavailability. Am J Clin Nutr 79:727-747

Michalski J, Deinzer A, Stich L et al (2020) Quercetin induces an immunoregulatory phenotype in maturing human dendritic cells. Immunobiology 225:151929

Miranda CL, Maier CS, Stevens JF (2012) Flavonoids. John Wiley \& Sons Ltd.: Chichester, UK.

Miranda A, Steluti J, Fisberg R et al (2016) Dietary intake and food contributors of polyphenols in adults and elderly adults of Sao Paulo: a population-based study. Br J Nutr 115:1061-1070

Müller L, Andree M, Moskorz W et al (2021) Age-dependent immune response to the Biontech/Pfizer BNT162b2 COVID-19 vaccination. MedRxiv. https://doi.org/10.1101/ 2021.03.03.21251066v1.abstract

Murase T, Nagasawa A, Suzuki J et al (2002) Beneficial effects of tea catechins on diet-induced obesity: stimulation of lipid catabolism in the liver. Int J Obes 26:1459-1464

Nguyen TTH, Woo H-J, Kang H-K et al (2012) Flavonoidmediated inhibition of SARS coronavirus 3C-like protease expressed in Pichia pastoris. Biotechnol Lett 34:831-838

Ngwa W, Kumar R, Thompson D et al (2020) Potential of flavonoid-inspired phytomedicines against COVID-19. Molecules 25:2707

Oh M-M, Carey E, Rajashekar C (2009) Environmental stresses induce health-promoting phytochemicals in lettuce. Plant Physiol Biochem 47:578-583

Oostra M, te Lintelo EG, Deijs M et al (2007) Localization and membrane topology of coronavirus nonstructural protein 4 : involvement of the early secretory pathway in replication. J Virol 81:12323-12336

Ortiz-Andrade RR, Sanchez-Salgado JC, Navarrete-Vazquez G et al (2008) Antidiabetic and toxicological evaluations of naringenin in normoglycaemic and NIDDM rat models and its implications on extra-pancreatic glucose regulation. Diabetes Obes Metab 10:1097-1104

Ovaskainen ML, Törrönen R, Koponen JM et al (2008) Dietary intake and major food sources of polyphenols in Finnish adults. J Nutr 138:562-566

Ovaskainen M-L, Torronen R, Koponen JM et al (2008) Dietary intake and major food sources of polyphenols in Finnish adults. J Nutr 138:562-566

Owuor PO, Obanda M, Nyirenda HE et al (2008) Influence of region of production on clonal black tea chemical characteristics. Food Chem 108:263-271 
Palacios R, Patiño EG, de Oliveira Piorelli R et al (2020) Double-blind, randomized, placebo-controlled phase iii clinical trial to evaluate the efficacy and safety of treating healthcare professionals with the adsorbed COVID-19 (inactivated) vaccine manufactured by sinovac-PROFISCOV: a structured summary of a study protocol for a randomised controlled trial. Trials 21:1-3

Panda V, Shinde P (2017) Appetite suppressing effect of Spinacia oleracea in rats: involvement of the short term satiety signal cholecystokinin. Appetite 113:224-230

Pandey P, Khan F, Rana AK et al (2021) A drug repurposing approach towards elucidating the potential of flavonoids as COVID-19 spike protein inhibitors. Biointerface Res Appl Chem 11:8482-8501

Park HJ, Lee CM, Jung ID et al (2009) Quercetin regulates Th1/ Th2 balance in a murine model of asthma. Int Immunopharmacol 9:261-267

Pendyala B, Patras, A (2020) In silico screening of food bioactive compounds to predict potential inhibitors of COVID-19 main protease (Mpro) and RNA-dependent RNA polymerase (RdRp). ChemRxiv. Preprint 12051927

Peng HL, Huang WC, Cheng SC et al (2018) Fisetin inhibits the generation of inflammatory mediators in interleukin-1betainduced human lung epithelial cells by suppressing the NF$\kappa \mathrm{B}$ and ERK1/2 pathways. Int Immunopharmacol 60:202-210

Perez-Jimenez J, Fezeu L, Touvier M et al (2011) Dietary intake of 337 polyphenols in French adults. Am J Clin Nutr 93:1220-1228

Pilkington V, Pepperrell T, Hill A (2020) A review of the safety of favipiravir-a potential treatment in the COVID-19 pandemic? J Virus Erad 6:45-51

Rabi FA, Al Zoubi MS, Kasasbeh GA et al (2020) SARS-CoV-2 and coronavirus disease 2019: what we know so far. Pathogens 9(3):231

Ragab FA, Yahya TA, El-Naa MM et al (2014) Design, synthesis and structure-activity relationship of novel semisynthetic flavonoids as antiproliferative agents. Eur J Med Chem 82:506-520

Rauf A, Khan R, Raza M et al (2015) Suppression of inflammatory response by chrysin, a flavone isolated from $\mathrm{Po}$ tentilla evestita Th. Wolf. In silico predictive study on its mechanistic effect. Fitoterapia 103:129-135

Rogerio AP, Dora CL, Andrade EL et al (2010) Anti-inflammatory effect of quercetin-loaded microemulsion in the airways allergic inflammatory model in mice. Pharmacol Res 61:288-297

Rosales-Mendoza S, Márquez-Escobar VA, González-Ortega O et al (2020) What does plant-based vaccine technology offer to the fight against COVID-19? Vaccines 8:183

Ross JA, Kasum CM (2002) Dietary flavonoids: bioavailability, metabolic effects, and safety. Annu Rev Nutr 22:19-34

Russo M, Moccia S, Spagnuolo C et al (2020) Roles of flavonoids against coronavirus infection. Chem-Biol Interact 328:109211

Ryzhikov A, Ryzhikov E, Bogryantseva M et al (2021) A single blind, placebo-controlled randomized study of the safety, reactogenicity and immunogenicity of the "EpiVacCorona" Vaccine for the prevention of COVID-19, in volunteers aged 18-60 years (phase I-II). Russ J Inf Immun $11: 283-296$
Sassi A, Mokdad Bzeouich I, Mustapha N et al (2017) Immunomodulatory potential of hesperetin and chrysin through the cellular and humoral response. Eur J Pharmacol 812:91-96

Seguin J, Brullé L, Boyer R et al (2013) Liposomal encapsulation of the natural flavonoid fisetin improves bioavailability and antitumor efficacy. Int J Pharm 444:146-154

Sehlakgwe PF, Lall N, Prinsloo G (2020) ${ }^{1}$ H-NMR metabolomics and LC-MS analysis to determine seasonal variation in a cosmeceutical plant Leucosidea sericea. Front Pharmacol 11:219-219

Sekiou O, Bouziane I, Frissou N et al (2020) In-silico identification of potent inhibitors of COVID-19 main protease $\left(\mathrm{M}^{\mathrm{pro}}\right)$ from natural products. International Journal of Biochemistry \& Physiology (IJBP) 5:000189

Shen Y, Tian P, Li D et al (2015) Chrysin suppresses cigarette smoke-induced airway inflammation in mice. Int $\mathrm{J}$ Clin Exp Med 8:2001-2008

Shoskes DA, Zeitlin SI, Shahed A et al (1999) Quercetin in men with category III chronic prostatitis: a preliminary prospective, double-blind, placebo-controlled trial. Urology 54:960-963

Simmons G, Zmora P, Gierer S et al (2013) Proteolytic activation of the SARS-coronavirus spike protein: cutting enzymes at the cutting edge of antiviral research. Antiviral Res 100:605-614

Sitzia C, Meregalli M, Belicchi M et al (2019) Preliminary evidences of safety and efficacy of flavonoids - and omega 3-based compound for muscular dystrophies treatment: a randomized double-blind placebo controlled pilot clinical trial. Front Neurol 10:755

Sohrab G, Hosseinpour-Niazi S, Hejazi J et al (2013) Dietary polyphenols and metabolic syndrome among Iranian adults. Int J Food Sci Nutr 64:661-667

Solnier J, Fladerer J-P (2020) Flavonoids: a complementary approach to conventional therapy of COVID-19? Phytochem Rev. https://doi.org/10.1007/s11101-020-09720-6

Sullivan M, Follis RH, Hilgartner M (1951) Toxicology of podophyllin. Exp Biol Med 77:269-272

Tahir Ul Qamar M, Alqahtani SM, Alamri MA et al (2020) Structural basis of SARS-CoV-2 3CL(pro) and antiCOVID-19 drug discovery from medicinal plants. J Pharm Anal 10:313-319

Tallei T, Tumilaar S, Niode N et al (2020) Potential of plant bioactive compounds as SARS-CoV-2 main protease $\left(\mathrm{M}^{\mathrm{pro}}\right)$ and spike $(\mathrm{S})$ glycoprotein inhibitors: a molecular docking study. Scientifica. https://doi.org/10.1155/2020/ 6307457

Thilakarathna SH, Rupasinghe HP (2013) Flavonoid bioavailability and attempts for bioavailability enhancement. Nutrients 5:3367-3387

Tian SS, Jiang FS, Zhang K, Zhu XX, Jin B, Lu JJ, Ding ZS (2014) Flavonoids from the leaves of Carya cathayensis Sarg. inhibit vascular endothelial growth factor-induced angiogenesis. Fitoterapia 92:34-40

Tresserra-Rimbau A, Medina-Remón A, Pérez-Jiménez J et al (2013) Dietary intake and major food sources of polyphenols in a Spanish population at high cardiovascular risk: the PREDIMED study. Nutr Metab Cardiovasc Dis 23:953-959 
Tutunchi H, Naeini F, Ostadrahimi A, Hosseinzadeh-Attar MJ (2020) Naringenin, a flavanone with antiviral and anti-inflammatory effects: a promising treatment strategy against COVID-19. Phytother Res 34:3137-3147

Tzotzos SJ, Fischer B, Fischer H et al (2020) Incidence of ARDS and outcomes in hospitalized patients with COVID-19: a global literature survey. Crit Care 24:516-516

Utomo RY, Ikawati, M, Meiyanto, E (2020) Revealing the potency of citrus and galangal constituents to halt SARSCoV-2 infection. Preprints 2020:2020030214

Viola H, Wasowski C, Levi de Stein M et al (1995) Apigenin, a component of Matricaria recutita flowers, is a central benzodiazepine receptors-ligand with anxiolytic effects. Planta Med 61:213-216

Vitale M, Masulli M, Rivellese A et al (2018) Dietary intake and major food sources of polyphenols in people with type 2 diabetes: The TOSCA. IT Study Eur J Nutr 57:679-688

Walls AC, Park YJ, Tortorici MA et al (2020) Structure, function, and antigenicity of the SARS-CoV-2 spike glycoprotein. Cell 181:281-292.e286

Wan Y, Shang J, Graham R et al (2020) Receptor recognition by the novel coronavirus from Wuhan: an analysis based on decade-long structural studies of SARS coronavirus. J Viro 94:e00120-e127

Wang Y, Gao L, Shan Y et al (2012) Influence of shade on flavonoid biosynthesis in tea (Camellia sinensis (L.) $\mathrm{O}$. Kuntze). Sci Hortic 141:7-16

Wang Y, Zhang D, Du G et al (2020) Remdesivir in adults with severe COVID-19: a randomised, double-blind, placebocontrolled, multicentre trial. Lancet 395:1569-1578

WHO (2020) WHO Director-General's opening remarks at the media briefing on COVID-19-11 March 2020.

Wise J (2021) Covid-19: European countries suspend use of Oxford-AstraZeneca vaccine after reports of blood clots. British Medical Journal 372:n699

Witkowska AM, Zujko ME, Waśkiewicz A et al (2015) Comparison of various databases for estimation of dietary polyphenol intake in the population of polish adults. Nutrients 7:9299-9308

Wong SK, Li W, Moore MJ et al (2004) A 193-amino acid fragment of the SARS coronavirus S protein efficiently binds angiotensin-converting enzyme 2. J Biol Chem 279:3197-3201

Wrapp D, Wang N, Corbett KS et al (2020) Cryo-EM structure of the 2019-nCoV spike in the prefusion conformation. Science 367:1260-1263

Wu C-H, Yang M-Y, Chan K-C et al (2010) Improvement in high-fat diet-induced obesity and body fat accumulation by a Nelumbo nucifera leaf flavonoid-rich extract in mice. J Agric Food Chem 58:7075-7081

Xiao J, Kai G (2012) A review of dietary polyphenol-plasma protein interactions: characterization, influence on the bioactivity, and structure-affinity relationship. Crit Rev Food Sci Nutr 52:85-101

Xiao Q, Park Y, Hollenbeck AR et al (2014) Dietary flavonoid intake and thyroid cancer risk in the NIH-AARP diet and health study. Cancer Epidemiol Biomark Prev 23:1102-1108

Xu Z, Yang L, Zhang X et al (2020) Discovery of potential flavonoid inhibitors against COVID-19 3CL proteinase based on virtual screening strategy. Front Mol Biosci 7:556481

Yahia EM, García-Solís P, Celis MEM (2019) Contribution of fruits and vegetables to human nutrition and health. Postharvest physiology and biochemistry of fruits and vegetables. Woodhead Publishing, Cambridge, pp 19-45

Yang N, Shen HM (2020) Targeting the Endocytic Pathway and Autophagy Process as a Novel Therapeutic Strategy in COVID-19. Int J Biol Sci 16:1724-1731

Yang H, Yang M, Ding Y et al (2003) The crystal structures of severe acute respiratory syndrome virus main protease and its complex with an inhibitor. Proc Natl Acad Sci U S A 100:13190

Yang T, Luo F, Shen Y et al (2012) Quercetin attenuates airway inflammation and mucus production induced by cigarette smoke in rats. Int Immunopharmacol 13:73-81

Yao L, Caffin N, D'Arcy B et al (2005) Seasonal Variations of Phenolic Compounds in Australia-Grown Tea (Camellia sinensis). J Agric Food Chem 53:6477-6483

Yao W, Cheng, J, Kandhare, AD et al (2019) Toxicological evaluation of a flavonoid, chrysin: morphological, behavioral, biochemical and histopathological assessments in rats. Drug Chem Toxicol 1-12

Ye J, Guan M, Lu Y et al (2019) Protective effects of hesperetin on lipopolysaccharide-induced acute lung injury by targeting MD2. Eur J Pharmacol 852:151-158

Yoshida H, Takamura N, Shuto T et al (2010) The citrus flavonoids hesperetin and naringenin block the lipolytic actions of TNF-alpha in mouse adipocytes. Biochem Biophys Res Commun 394:728-732

Zamora-Ros R, Knaze V, Romieu I, Scalbert A, Slimani N, Clavel-Chapelon F, Touillaud M, Perquier F, Skeie G, Engeset D, Weiderpass E (2013) Impact of thearubigins on the estimation of total dietary flavonoids in the European Prospective Investigation into Cancer and Nutrition (EPIC) study. Eur J Clin Nutr 67(7):779-782

Zamora-Ros R, Knaze V, Rothwell JA et al (2016) Dietary polyphenol intake in Europe: the European Prospective Investigation into Cancer and Nutrition (EPIC) study. Eur J Nutr 55:1359-1375

Zamora-Ros R, Biessy C, Rothwell JA et al (2018) Dietary polyphenol intake and their major food sources in the Mexican Teachers' Cohort. Br J Nutr 120:353-360

Zandalinas SI, Sales C, Beltrán J et al (2017) Activation of Secondary Metabolism in Citrus Plants Is Associated to Sensitivity to Combined Drought and High Temperatures. Front Plant Sci 7:1954-1954

Zarei M, Mohammadi S, Shahidi S et al (2017) Effects of Sonchus asper and apigenin-7-glucoside on nociceptive behaviors in mice. J Pharm Pharmacogn Res 5:227-237

Zeinali M, Rezaee SA, Hosseinzadeh H (2017) An overview on immunoregulatory and anti-inflammatory properties of chrysin and flavonoids substances. Biomed Pharmacother 92:998-1009

Zhang X, Wang G, Gurley EC, Zhou H (2014) Flavonoid apigenin inhibits lipopolysaccharide-induced inflammatory response through multiple mechanisms in macrophages. PLoS One 9(9):e107072

Zhang X, Huang H, Zhao X, Lv Q, Sun C, Li X, Chen K (2015) Effects of flavonoids-rich Chinese bayberry (Myrica rubra 
Sieb. et Zucc.) pulp extracts on glucose consumption in human HepG2 cells. J Funct Foods 14:144-153

Zhang R, Wang X, Ni L, Di X, Ma B, Niu S, Liu C, Reiter RJ (2020) COVID-19: Melatonin as a potential adjuvant treatment. Life Sci 250:117583

Zobeiri M, Belwal T, Parvizi F et al (2018) Naringenin and its Nano-formulations for Fatty Liver: Cellular Modes of
Action and Clinical Perspective. Curr Pharm Biotechnol 19:196-205

Publisher's Note Springer Nature remains neutral with regard to jurisdictional claims in published maps and institutional affiliations. 